Article

\title{
Unravelling the High-Pressure Behaviour of Dye-Zeolite L Hybrid Materials
}

\author{
Lara Gigli ${ }^{1}$, Rossella Arletti ${ }^{2,3, *}$, Ettore Fois ${ }^{4}$, Gloria Tabacchi ${ }^{4}$ (i) , Simona Quartieri ${ }^{5}$, \\ Vladimir Dmitriev ${ }^{6}$ and Giovanna Vezzalini ${ }^{7}$ (D) \\ 1 Elettra-Sincrotrone Trieste, Strada Statale 14-km 163,5 in AREA Science Park, 34149 Basovizza, Trieste, Italy; \\ lara.gigli@elettra.eu \\ 2 Dipartimento di Scienze della Terra, Università degli Studi di Torino, Via Valperga Caluso 35, \\ 10125-Torino, Italy \\ 3 Interdepartmental Centre "Nanostructure Interfaces and Surfaces NIS", Via Pietro Giuria 7, \\ 10125-Torino, Italy \\ 4 Dipartimento di Scienza e Alta Tecnologia and INSTM, Università degli Studi dell'Insubria, Via Valleggio 9, \\ I-22100 Como, Italy; ettore.fois@uninsubria.it (E.F.); gloria.tabacchi@uninsubria.it (G.T.) \\ 5 Dipartimento di Scienze Matematiche e Informatiche, Scienze Fisiche e Scienze della Terra, \\ Università degli Studi di Messina, Viale Ferdinando Stagno d'Alcontres 31, 98166-Messina S.Agata, Italy; \\ simona.quartieri@unime.it \\ 6 Swiss-Norwegian Beam Line at ESRF, BP220, 38043 Grenoble CEDEX, France; dmitriev@esrf.fr \\ 7 Dipartimento di Scienze Chimiche e Geologiche, Università degli Studi di Modena e Reggio Emilia, \\ Via Giuseppe Campi 103, 41125-Modena, Italy; mariagiovanna.vezzalini@unimore.it \\ * Correspondence: rossella.arletti@unito.it; Tel.: +39-011-670-5129
}

Received: 11 January 2018; Accepted: 29 January 2018; Published: 2 February 2018

\begin{abstract}
Self-assembly of chromophores nanoconfined in porous materials such as zeolite L has led to technologically relevant host-guest systems exploited in solar energy harvesting, photonics, nanodiagnostics and information technology. The response of these hybrid materials to compression, which would be crucial to enhance their application range, has never been explored to date. By a joint high-pressure in situ synchrotron $\mathrm{X}$-ray powder diffraction and ab initio molecular dynamics approach, herein we unravel the high-pressure behaviour of hybrid composites of zeolite L with fluorenone dye. High-pressure experiments were performed up to $6 \mathrm{GPa}$ using non-penetrating pressure transmitting media to study the effect of dye loading on the structural properties of the materials under compression. Computational modelling provided molecular-level insight on the response to compression of the confined dye assemblies, evidencing a pressure-induced strengthening of the interaction between the fluorenone carbonyl group and zeolite L potassium cations. Our results reveal an impressive stability of the fluorenone-zeolite L composites at GPa pressures. The remarkable resilience of the supramolecular organization of dye molecules hyperconfined in zeolite L channels may open the way to the realization of optical devices able to maintain their functionality under extreme conditions.
\end{abstract}

Keywords: high-pressure chemistry; nanomaterials; supramolecular chemistry; self-assembly; X-ray diffraction; zeolites; density functional calculations; ab initio molecular dynamics; structural refinements; artificial antenna systems; organic-inorganic hybrid materials

\section{Introduction}

Zeolites are crystalline natural or synthetic porous materials consisting of corner-sharing tetrahedral units, characterized by a regular arrangement of cages and channels of molecular size [1,2]. The nanometric-scale geometry of zeolite pore systems allows the intensive use of zeolites in several fields such as in molecular separation processes and in heterogeneous catalysis [3,4]. 
Besides being instrumental in traditional applications, the ordered arrangements of zeolitic cages has long been recognized as a route to create advanced materials based on confined, organized nanostructures, such as luminescent metal clusters [5-8], quantum dots/wires [9] or lanthanides [10]. Turning to more complex guests, the incorporation of fluorescent molecules in zeolite cages generally enhances their emission properties [11-13] because it allows to obtain high concentrations of chromophores while limiting the formation of aggregates (which negatively affect the emission intensity) [14]. Incorporated dyes exhibit a preferential orientation of the electronic transition dipole moments, which endows -dye-zeolite host-guest compounds with exceptional energy transfer properties, similar to antenna systems in natural photosynthetic organisms [11,15-25].

Zeolite L (Figure 1) features a unique one-dimensional 12-membered (12 MR) channel system running along the [001] direction. One of the greatest advantages of zeolite L is that high-quality crystals with a desired aspect ratio can be easily synthesized [26,27]. Also importantly, their surfaces can be modified selectively by the attachment of molecules carrying a specific chemical functionality [28,29], thus allowing zeolite L crystals to be sealed (to avoid leakage of dye molecules) [30-32], or interfaced to molecules [33], nanoparticles [34,35], living cells [36,37] and rigid supports [38]. Based on these features, zeolite L has been fully exploited as matrix for dye encapsulation and the molecules organization has been hierarchically enhanced up to the macroscopic scale, resulting into functional materials with remarkable electro-optical and energy-transfer performances, already exploited in devices [39]. Composites based on zeolite $\mathrm{L}$ as host matrix have reached an advanced stage of development [40] and are presently used as effect pigments [41], in solar energy harvesting [11], or in biomedical technology $[42,43]$.

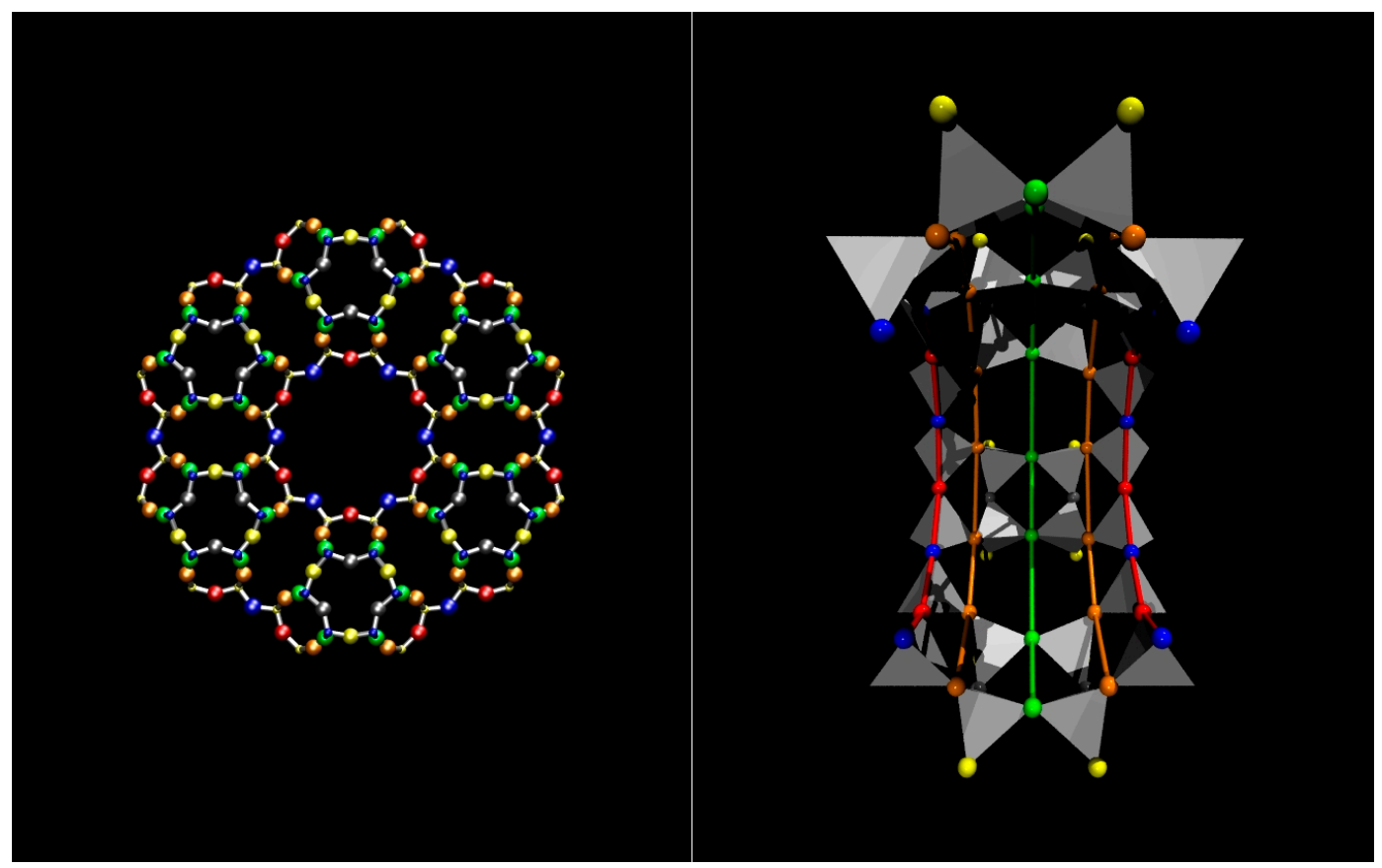

Figure 1. Zeolite L and its one-dimensional nanochannels. Left panel: View along the channel axis (parallel to [001]) highlighting the larger channel, delimited by a 12-membered ring (12 MR) and surrounded by smaller $8 \mathrm{MR}$ channels. The tetrahedral atoms of the framework $(\mathrm{T}=\mathrm{Si}, \mathrm{Al})$ are represented by small balls, $\mathrm{O}$ atoms by big balls. Colour codes: $\mathrm{T} 1=$ yellow, $\mathrm{T} 2=$ blue, $\mathrm{O} 1=$ blue (big), O2 = red, O3 = grey, O4 = orange, O5 = yellow (big), O6 = green; Right panel: Half-section of the $12 \mathrm{MR}$ channel, viewed perpendicular to the $12 \mathrm{MR}$ channel axis. T-atoms ( $\mathrm{Si}, \mathrm{Al})$ are represented by grey tetrahedra, $\mathrm{O}$ atoms by big balls, with same colour codes as in the left panel. The coloured lines are a guide to the eye drawn to represent the different rings in the cage and to evidence the channel curvature under a perspective view. 
Such ongoing progress in applications has been accompanied, in the latest years, by a deeper molecular-level understanding of the confined photoactive assemblies, which has been achieved through computational modelling [44-50], often combined with multi-technique experimental analyses [45,50-57]. The key role of water in tuning the organization of the confined chromophores has been revealed $[45,46,58]$, as well as the stabilizing effect of potassium cations in composites with carbonyl dyes [44,57,59].

The high-pressure behaviour of zeolites has been intensively studied in the last 15 years, as documented in various reviews $[50,60-66]$, both with pore penetrating and non-penetrating pressure transmitting media (PTM). One reason for this interest is that high pressures, combined with the confining environments of nanometric pores, may reveal unexpected chemical phenomena (e.g., pressure-induced hydration [67-82], ionic conductivity [83], guest exchange [84-88], or realization of new materials otherwise unattainable [89-97]). With this paper we would like to answer the question: how do confined supramolecular assemblies of water and chromophores respond to compression?

In this paper, it is reported the study of the high-pressure evolution of zeolite-dye hybrids. Specifically, we selected the zeolite L (ZL)-fluorenone (FL) hybrid (ZL/FL from now on), subject of previous investigations performed by our group [56]. We are interested in exploring whether the compression could favour a more ordered distribution of the dye molecules in the zeolite $\mathrm{L}$ channels and if this process leads to an improvement of the optical properties of the hybrid material. In fact, it has been shown that the properties of dye-zeolite systems depend on the molecular orientation, arrangement and packing inside the channel $[14,15,20,44-46,56,58]$, which control the guest-guest and host-guest interactions. To unravel and understand at molecular level the compression behaviour of the inclusion composites we adopted an integrated experimental-theoretical approach, based on the use of high pressure (HP) in situ synchrotron X-ray powder diffraction (XRPD) and ab initio molecular dynamics [98] simulations, which already captured a nice example of pressure-induced supramolecular organization in zeolites [97]. Herein, high-pressure experiments were performed up to $6 \mathrm{GPa}$ using non-penetrating pressure transmitting media on samples characterized by three different contents of fluorenone molecules per unit cell, in order to verify how the dye loading influences the structural properties of the hybrid material under compression.

\section{Materials and Methods}

\subsection{Zeolite Dye Hybrids: Structural Details at Ambient Conditions}

The LTL framework [1] is built from columns of cancrinite cages stacked with double six membered rings (D6R) along the $c$ axis. These columns are connected to form larger circular 12-ring (12 MR) channels and smaller elliptical 8-ring (8 MR) channels both running along the $c$ axis ( $8 \mathrm{MR} \perp$ [001], channel \| [001]). The main channels—with dimensions ranging from of 7.1 to $12 \AA$-are connected to the parallel $8 \mathrm{MR}$ channels by a non-planar boat shaped $8 \mathrm{MR}$ (8 MR \| [001]). In the as-synthesized K-LTL [56,99] [ $\mathrm{K}_{8.46}\left(\mathrm{Al}_{8.35} \cdot \mathrm{Si}_{27.53}\right) \mathrm{O}_{72} \cdot 17.91 \mathrm{H}_{2} \mathrm{O}$, s.g. P6/mmm, $\left.a=18.3795, c=7.5281\right]$, three positions of $\mathrm{K}$ cations were located: site $\mathrm{KB}$ in cancrinite cage, site $\mathrm{KC}$ in the $8 \mathrm{MR}$ and site KD in the main 12 MR channel.

The ZL/FL composites here investigated are those synthesized and previously characterized at ambient pressure $\left(P_{\mathrm{amb}}\right)$ by Gigli et al. [56]. Specifically, three hybrids at different fluorenone loadings were investigated, containing $0.5,1$ and 1.5 molecules of colorant per unit cell (from now on ZL/0.5FL, ZL/1FL, ZL/1.5FL).

In the structures of ZL/0.5FL and ZL/1FL at $P_{\mathrm{amb}}$ [56] the fluorenone molecules are sited in the $12 \mathrm{MR}$ on the mirror planes parallel to the $c$ axis, statistically occupying only one of the six equivalent positions (Figure 2a,b). The oxygen of the carbonyl group of the FL molecule is strongly interacting with potassium atoms KD located along the walls of the main channel. Along with the dye, water molecules were also located in the 12 MR channel: specifically, 14.7 molecules/u.c. in the ZL/0.5FL composite and 9.7 molecules/u.c. in the $\mathrm{ZL} / 1 \mathrm{FL}$ one. The structure of $\mathrm{ZL} / 1.5 \mathrm{FL}$ resulted to be too 
complex to be unravelled by structural refinement (i.e., due to high symmetry constrains imposed and to the low electronic density of the atoms), thus a theoretical approach was used. Density functional calculations were indeed able to provide a reliable structural model of the packing of fluorenone inside the composite at room pressure conditions: more specifically, the supramolecular organization of the confined dyes consisted of pairs of molecules-positioned roughly on top of each other, with their long axes nearly parallel to the channel axis-alternated by a dye molecule oriented at about $45^{\circ}$ with respect to the zeolite channel axis (Figure 3) [56]. Moreover, calculations evidenced that such a peculiar arrangement-originally called "dye-nanoladder"—was due not only to the structural constraints imposed by the ZL-nanochannel geometry but also to a complex network of intermolecular interactions, among which the dominant one was the coordination of the carbonyl oxygen to the $\mathrm{K}^{+}$ extra framework cations (KD)).
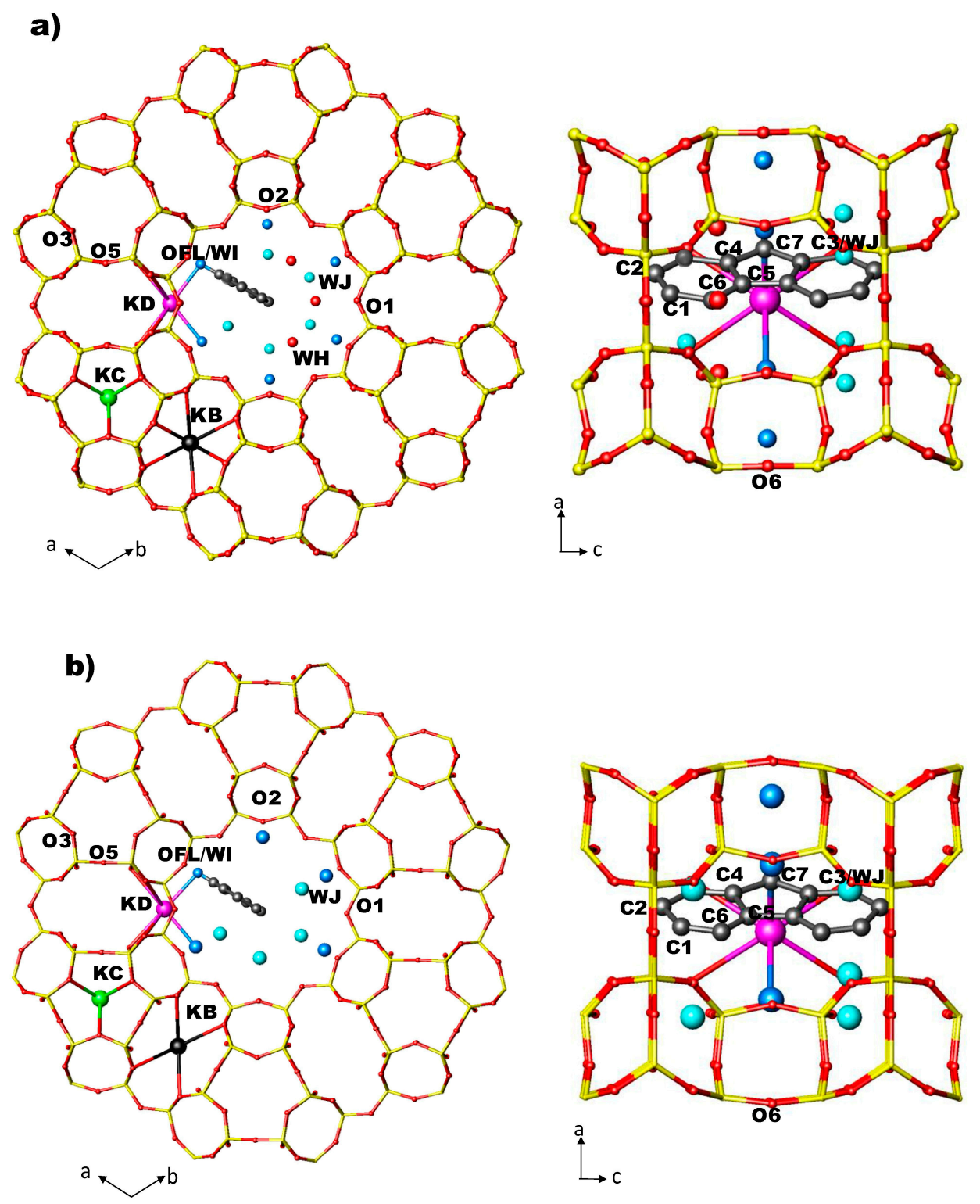

Figure 2. Arrangement of FL and water molecules in the $12 \mathrm{MR}$ channel along [001] and along [010] directions in ZL/0.5FL (a) and ZL/1.0FL (b) at $P_{\mathrm{amb}}$ [56]. 


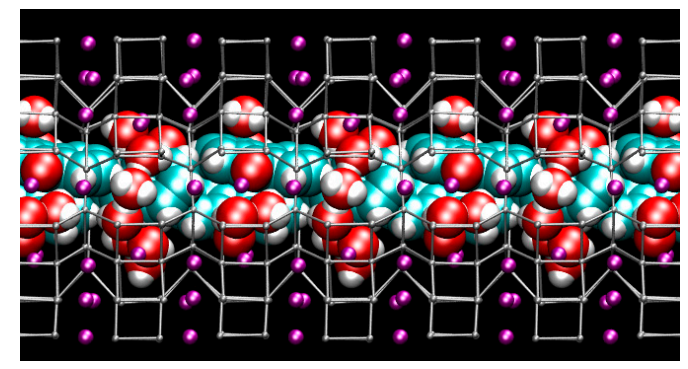

Figure 3. Structure of the hydrated $\mathrm{ZL} / 1.5 \mathrm{FL}$ model at $P_{\mathrm{amb}}$-(side view of the $12 \mathrm{MR}$ channel $\|$ [001] axis [56]). Tetrahedral atoms $(\mathrm{T}=\mathrm{Si}, \mathrm{Al})$ of the zeolite $\mathrm{L}$ framework are represented as grey stick-and-ball. $\mathrm{K}^{+}=$purple spheres. Water and fluorenone atoms are depicted in van der Waals representation (cyan $=\mathrm{C}$, red $=\mathrm{O}$, white $=\mathrm{H}$ ) to highlight the close-packing arrangement of guest species inside the zeolite L nanochannel.

\subsection{Synchrotron X-ray Powder Diffraction Experiments}

All the samples were studied with silicon oil (s.o.) as non-penetrating PTM. The in-situ HP XRPD experiments were performed at the SNBL1 (BM01a) beamline at ESRF (European Synchrotron Radiation Facility) with fixed wavelength of $0.72 \AA$, using a modified Merril-Basset Diamond Anvil Cell (DAC) $[100,101]$. The pressure was measured using the ruby fluorescence method on the non-linear hydrostatic pressure scale [102]. The estimated error in the pressure values is $0.05 \mathrm{GPa}$. Bidimensional diffraction patterns were recorded on a PILATUS2M-Series detector (commercialised by Dectris-Switzerland, Baden-Dättwil, Switzerland) (pixel dimension $172 \mu \mathrm{m}$ ) at a fixed distance of $195 \mathrm{~mm}$ from the sample; the exposure times were $300 \mathrm{~s}$ for each collected pattern. One dimensional diffraction patterns were obtained in the $2 \theta$ range $0^{\circ}-43^{\circ}$ by integrating the two dimensional images with the program Fit2D [103]. Some patterns were collected upon pressure release (labelled (rev) in Tables and Figures). Unit cell parameters determination through Rietveld refinements was possible for all the ramps (Table S1). The Rietveld structural refinements were performed on the ZL/0.5FL, ZL/1FL composites at 2.09 and $2.01 \mathrm{GPa}$, respectively (from now on will be both labelled $2 \mathrm{GPa}$ (i.e., the highest pressures at which the quality of the diffraction patterns allowed the structural refinement) and upon complete decompression $\left(P_{\mathrm{amb}}(\mathrm{rev})\right)$. All the structural refinements were carried out in the space group P6/mmm starting from the atomic coordinates reported by Gigli et al. [56], using the GSAS package [104] with EXPGUI interface [105]. The background curves were fitted by a Chebyschev polynomial function with 24 coefficients for all the samples. The pseudo-Voight profile function proposed by Thomson et al. [106] was used with refined Gaussian (GW) e Lorentzian (LX) terms and a $0.1 \%$ cut-off was applied to the peak intensities. The scale factor and $2 \theta$ zero shift were accurately refined in all patterns of the data set. Soft constraints were imposed on tetrahedral bond lengths $(\mathrm{Si}-\mathrm{O}=1.63 \AA)$ as well as on the $\mathrm{C}-\mathrm{C}$ (in the range $1.39-1.48 \AA)$ and $\mathrm{C}-\mathrm{O}(1.19 \AA)$ distances, with tolerance values of $0.03 \AA$. The isotropic displacement parameters were constrained in the following way: the same value for all tetrahedral cations, a second value for all framework oxygen atoms and a third value for water molecules. For both the ZL/FL systems, isotropic displacement parameters for FL atoms were kept equal to $P_{\mathrm{amb}}$ values. Occupancy factor for FL were not varied and kept equal

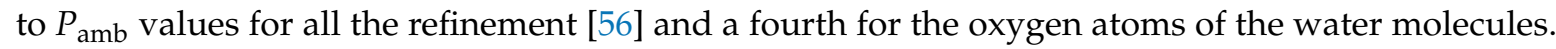
Details of the structural refinements are reported in Table 1. Atomic coordinates, site occupancies and isotropic displacement parameters are reported in Table S2 while interatomic distances in Table S3.

\subsection{Theoretical Modelling}

The behaviour of the ZL/1.5FL sample was simulated both at ambient conditions and at compression corresponding to $1.95 \mathrm{GPa}$ in s.o. adopting the experimental cell parameters. The simulation cell consisted of two crystallographic cells along the $12 \mathrm{MR}$ channel (c axis). The corresponding stoichiometry of the simulated system is $\mathrm{K}_{18}\left[\mathrm{Al}_{18} \mathrm{Si}_{54} \mathrm{O}_{144}\right] 13 \cdot\left(\mathrm{H}_{2} \mathrm{O}\right) 3 \cdot \mathrm{FL}$, as determined in [56]. The systems were simulated, 
at room temperature, via first-principles molecular dynamics [98]. The PBE approximation to Density Functional Theory was adopted for the electron-electron interactions and augmented with dispersion corrections via the Grimme D2 approach [107] for the FL-FL interactions. Pseudopotentials and basis set expansion were the same adopted in [56]. Such a computational approach has demonstrated to provide a satisfactory description of diverse systems involving adsorbate-surfaces [108-122] or host-guest interactions [123-134] including also processes at zeolite interfaces [32,59] and high pressure conditions [97,135-140].

Equations of motion were integrated with the Car Parrinello Lagrangean $[98,141]$ adopting a time step of $0.121 \mathrm{fs}$. The starting configuration for the $P_{\mathrm{amb}}$ simulation corresponded to the minimum energy structure determined in [56]. An equilibration trajectory of 5 ps was followed by 12 ps of production run. The final configuration obtained at $P_{\mathrm{amb}}$ conditions was used as starting configuration for the $1.95 \mathrm{GPa}$ compression simulation. Also in this case, data were gathered from a 12 ps trajectory after a 5 ps equilibration run. In all cases, temperature was controlled via Nose-Hoover thermostats set at $300 \mathrm{~K}$. In all the simulations, performed with the CPMD code [142], no constraints was imposed to the systems except for the experimentally determined cell parameters.

\section{Results}

\subsection{Structure of the ZL-FL Composites at Different Pressure Conditions}

Figure 4 shows selected powder patterns of the three ZL-FL composites compressed in s.o. as a function of pressure. With increasing pressure the peak intensities decrease and the peak profiles become broader. Notwithstanding this, complete X-ray amorphization is not achieved up to the highest investigated pressure (about $6 \mathrm{GPa}$ ). All the observed peaks are consistent with the $\mathrm{P} / 6 \mathrm{mmm}$ s.g., thus ruling out any $P$-induced phase transition. The patterns collected upon decompression demonstrate that the $P$-induced effects are almost completely reversible. In fact, the features of the ambient-pressure pattern $\left(P_{\mathrm{amb}}\right)$ and the unit cell parameters are rather well recovered upon $P$ release. The decrease of the cell parameters for ZL/0.5FL, ZL/1FL, ZL/1.5FL samples up to $6 \mathrm{GPa}$ are: $\Delta a=-3 \%,-2.7 \%$, $-2.3 \% ; \Delta c=-4.6 \%,-4.4 \%,-3.7 \%$ accounting for a $\Delta \mathrm{V}=-10.1 \%,-9.5 \%$ and $-8.0 \%$, respectively (See Figure 5 and Table S1). These values indicate that the compressibility changes with the loading and that the FL molecules hosted in the channels stiffen the structure.

The hexagonal lattice undergoes a slight anisotropic compression (Figure 5), with $c$ as the most compressible axis. This is probably due to the presence of bonds among the FL carbonyl groups and KD potassium cations, lying along the $a$ direction, that stiffen the structure.

a

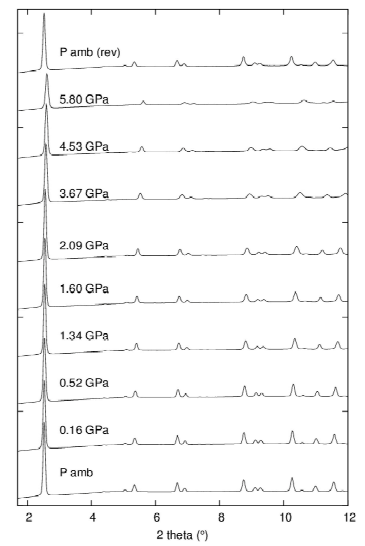

b

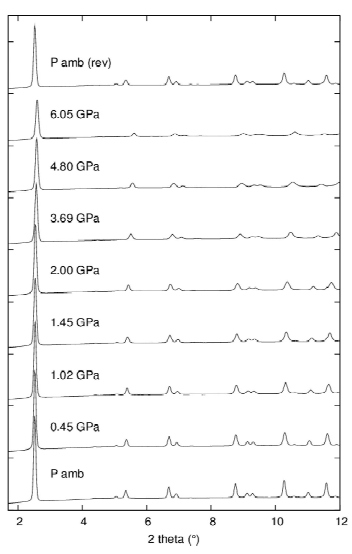

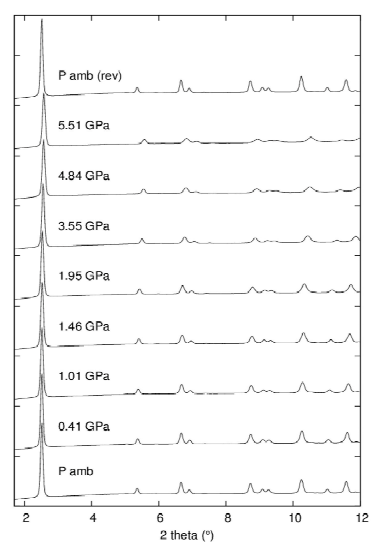

Figure 4. Selected integrated powder patterns (in the $2 \theta$ range $3^{\circ}-12^{\circ}$ ) of ZL/0.5FL (a), ZL/1FL (b) and ZL/1.5FL (c) compressed in s.o., reported as a function of pressure. The powder patterns at the top $\left(P_{\mathrm{amb}}(\mathrm{rev})\right)$ is collected upon pressure release. 
a

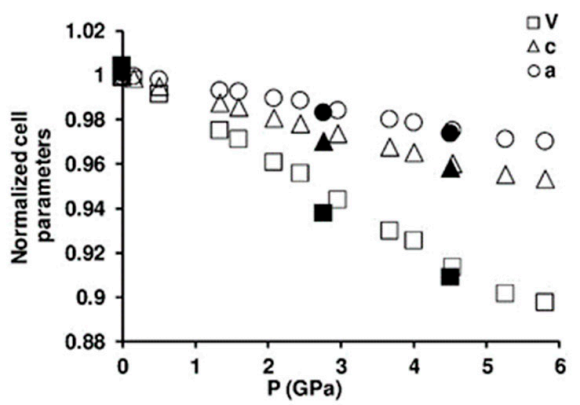

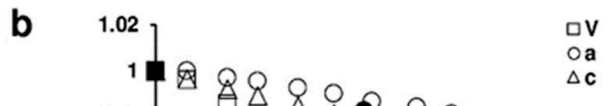

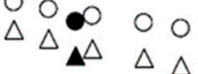

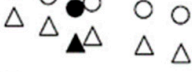

ㅁ.

뭄

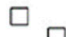

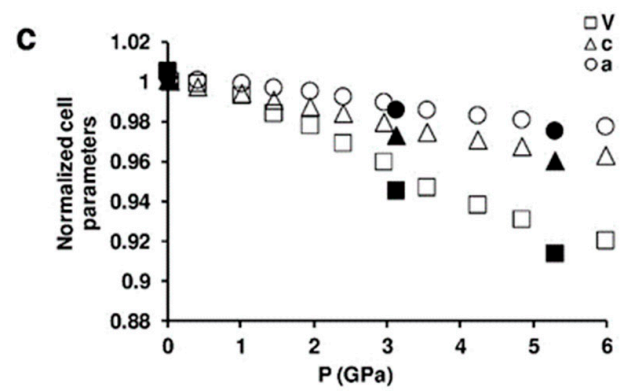

Figure 5. Variations of normalized lattice parameters as a function of pressure for: (a) ZL/0.5FL; (b) ZL/1FL; (c) ZL/1.5FL. The errors associated with the cell parameters are smaller than the symbols used. The full black symbols are associated to decompression ramp.

Table 1. Experimental and structural parameters for selected XRPD refinements performed on the ZL/0.5FL and ZL/1FL composites compressed in silicon oil (s.o.) at 2 GPa and upon decompression $\left(P_{\mathrm{amb}}(\mathrm{rev})\right) .{ }^{1}$ From Ref. [56].

\begin{tabular}{|c|c|c|c|}
\hline \multicolumn{4}{|c|}{ ZL/0.5FL } \\
\hline$P(G P a)$ & $P_{\mathrm{amb}}{ }^{1}$ & $2 \mathrm{GPa}$ & $P_{\text {amb }}$ (rev) \\
\hline Space group & $\mathrm{P} 6 / \mathrm{mmm}$ & $\mathrm{P} 6 / \mathrm{mmm}$ & $\mathrm{P} 6 / \mathrm{mmm}$ \\
\hline$a(\AA)$ & $18.3860(4)$ & $18.1788(9)$ & $18.4349(8)$ \\
\hline$c(\AA)$ & $7.5228(2)$ & $7.3866(4)$ & $7.5498(6)$ \\
\hline$V(\AA)$ & $2202.4(1)$ & $2114.0(2)$ & $2222.0(2)$ \\
\hline R F $F^{* * 2}(\%)$ & 7.3 & 12.3 & 11.2 \\
\hline No. variables & 73 & 82 & 82 \\
\hline No. obs. & 1319 & 2474 & 2474 \\
\hline No. refl. & 944 & 618 & 618 \\
\hline \multicolumn{4}{|c|}{ ZL/1FL } \\
\hline$P(G P a)$ & $P_{\mathrm{amb}}{ }^{1}$ & $2 \mathrm{GPa}$ & $P_{\mathrm{amb}}$ (rev) \\
\hline Space group & $\mathrm{P} 6 / \mathrm{mmm}$ & $\mathrm{P} 6 / \mathrm{mmm}$ & $\mathrm{P} 6 / \mathrm{mmm}$ \\
\hline$a(\AA)$ & $18.3940(6)$ & $18.250(1)$ & $18.3962(8)$ \\
\hline$c(\AA)$ & $7.5203(3)$ & $7.4063(5)$ & 7.5189 (4) \\
\hline$V(\AA)$ & $2203.5(1)$ & $2136.3(2)$ & $2203.6(2)$ \\
\hline $\mathrm{R} \mathrm{F}^{* * 2}(\%)$ & 7.8 & 11.9 & 13.7 \\
\hline No. variables & 81 & 83 & 83 \\
\hline No. obs. & 1319 & 2422 & 2404 \\
\hline No. refl. & 946 & 679 & 639 \\
\hline
\end{tabular}




\section{Framework Modifications}

The framework $P$-induced deformations can be summarized as follows (see Table 2 and Figure 6):

(i) In the ZL/0.5FL at $2 \mathrm{GPa}$, both the diameters (O1-O1 and $\mathrm{O} 2-\mathrm{O} 2)$ of the $12 \mathrm{MR}$ shorten. The shortening of the 12 MR O1-O1 diameter is reflected in the lengthening of the O1-O1 diameter of 8 MR channel (|| [001]), which becomes more elliptical. Upon pressure release, the original values of the $12 \mathrm{MR}$ diameters are almost regained (remaining slightly smaller than those observed at $P_{\mathrm{amb}}$ ), while the $8 \mathrm{MR}$ ones are strongly lengthened with respect to the original values, in accordance with the increase of $a$ parameter (see Table 1 and Table S1).

(ii) In the ZL/1FL sample, O2-O2 (12 MR) diameter decreases with pressure while O1-O1 increases-probably due to the presence of a larger numbers of FL molecules in the channels with respect to the ZL/0.5FL system. The O1-O1 (12 MR) increase is balanced by the decrease of O1-O1 diameter of the $8 \mathrm{MR}$ channel running alongside (\| [001]): as a consequence, $8 \mathrm{MR}$ becomes less elliptical. Upon pressure release, the 12 MR opening remains slightly smaller than that observed at $P_{\mathrm{amb}}$. The significant enlargement of the 8 MR leads to an overall value for $a$ parameter comparable with that at $P_{\text {amb }}$.

(iii) The $8 \mathrm{MR}$ window (8 MR \|[001]) (O1-O1, O6-O6), parallel to the $c$ axis, becomes more circular at $2 \mathrm{GPa}$ in both the samples. Once the pressure is released the starting values are regained.

(iv) The O3-O5-O3 and O5-O3-O5 angle variations indicate that the D6R slightly increases its ditrigonal distortion in both samples. Upon pressure release the $P_{\mathrm{amb}}$ features are almost recovered.

Table 2. Experimental framework distances obtained from the refinements performed on the ZL/0.5FL and ZL/1.0FL composites at $P_{\mathrm{amb}}$ (from Ref. [56]), at $2 \mathrm{GPa}$ and upon decompression ( $P_{\mathrm{amb}}(\mathrm{rev})$ ). ${ }^{1}$ From ref. [56].

\begin{tabular}{|c|c|c|c|c|c|c|}
\hline & \multicolumn{3}{|c|}{ ZL/0.5FL } & \multicolumn{3}{|c|}{ ZL/1FL } \\
\hline & $P_{\mathrm{amb}}{ }^{1}$ & $2 \mathrm{GPa}$ & $P_{\mathrm{amb}}(\mathrm{rev})$ & $P_{\mathrm{amb}}{ }^{1}$ & $2 \mathrm{GPa}$ & $P_{\text {amb }}$ (rev) \\
\hline & \multicolumn{3}{|c|}{$12 \mathrm{MR}$} & \multicolumn{3}{|c|}{$12 \mathrm{MR}$} \\
\hline O1-O1 & 10.10 & 9.76 & 9.95 & 10.14 & 10.30 & 10.00 \\
\hline $\mathrm{O} 2-\mathrm{O} 2$ & 10.52 & 10.43 & 10.56 & 10.46 & 10.12 & 10.45 \\
\hline & \multicolumn{3}{|c|}{$8 \mathrm{MR} \perp[001]$} & \multicolumn{3}{|c|}{$8 \mathrm{MR} \perp[001]$} \\
\hline 01-01 & 8.29 & 8.41 & 8.48 & 8.26 & 7.95 & 8.39 \\
\hline O5-O5 & 4.63 & 4.54 & 4.75 & 4.60 & 4.70 & 5.22 \\
\hline \multirow[t]{2}{*}{${ }^{*} E$} & 1.79 & 1.85 & 1.78 & 1.79 & 1.69 & 1.61 \\
\hline & \multicolumn{3}{|c|}{$8 \mathrm{MR}$ || [001] } & \multicolumn{3}{|c|}{$8 \mathrm{MR}$ || [001] } \\
\hline O1-01 & 7.52 & 7.39 & 7.54 & 7.52 & 7.41 & 7.51 \\
\hline \multirow[t]{2}{*}{ O6-06 } & 4.66 & 4.45 & 4.63 & 4.68 & 4.42 & 4.60 \\
\hline & \multicolumn{3}{|c|}{ D6R } & \multicolumn{3}{|c|}{ D6R } \\
\hline O5-O3-O5 & 147.67 & 151.82 & 145.63 & 149.18 & 152.6 & 143.00 \\
\hline O3-O5-O3 & 91.68 & 86.51 & 93.23 & 90.09 & 87.7 & 95.97 \\
\hline \multicolumn{7}{|c|}{$12 \mathrm{MR}$ maximum diameter } \\
\hline O6-06 & 15.60 & 15.44 & 15.69 & 15.67 & 15.67 & 15.91 \\
\hline
\end{tabular}




\section{a)}
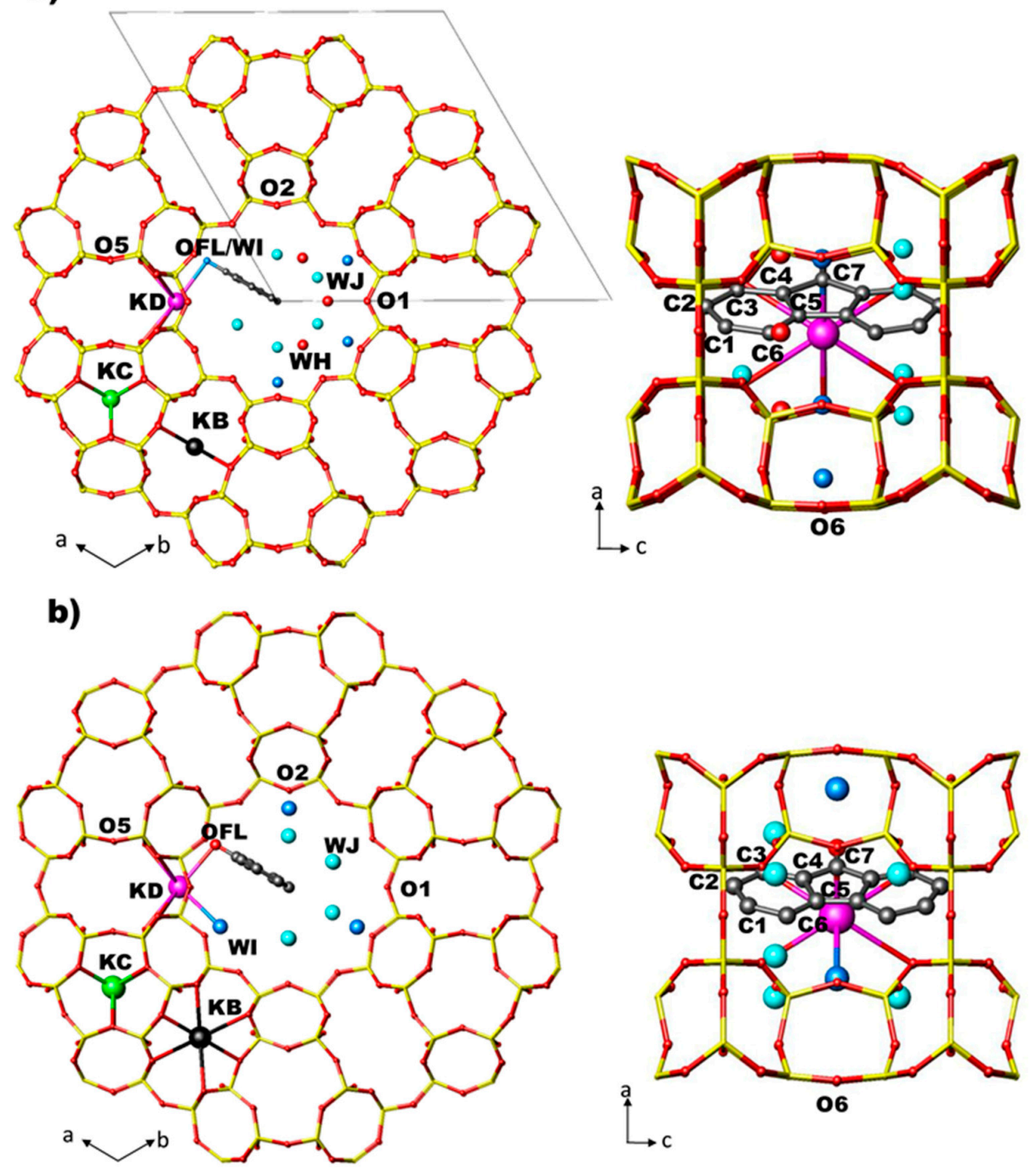

Figure 6. Arrangement of FL and water molecules in the $12 \mathrm{MR}$ channel along [001] and along [010] directions in the ZL/0.5FL and ZL/1.0FL composites $(\mathbf{a}, \mathbf{b})$ at $2 \mathrm{GPa}$, as obtained by Rietveld refinements.

\section{Extra Framework Species}

The distribution of the $\mathrm{K}$ cations in both composites at $P_{\mathrm{amb}}$ can be described as follows (see Table S2 and S3):

(i) site $\mathrm{KB}$-in the centre of the cancrinite cage—is fully occupied and coordinated to six framework oxygen atoms $\mathrm{O} 3$;

(ii) site $\mathrm{KC}$-in the centre of the $8 \mathrm{MR}$ channel—is fully occupied and coordinated to four oxygen atoms $\mathrm{O5}$;

(iii) site KD—near the wall of the main $12 \mathrm{MR}$ channel—is partially occupied and coordinated to six oxygen atoms $(\mathrm{O} 4, \mathrm{O} 6)$, two water molecules $(\mathrm{WH}$ and $\mathrm{WI})$ and to the oxygen atom of FL molecule (OFL).

At $P_{\mathrm{amb}}$, in ZL/0.5FL and ZL/1.0FL composites the water molecules (14.7 and 9.7 per unit cell, respectively) are distributed over three extra framework sites (WH, WI, WJ). All of them are located in the main channel. WH site is present only in ZL/0.5FL composite, the other two sites have the same positions of the oxygen atom and of the $\mathrm{C} 3$ carbon atom of FL molecule (labelled OFL/WI and C3/WJ, respectively, in Ref. [56]). 
Upon compression at $2 \mathrm{GPa}$ the following structural features are observed:

(i) the distances between $\mathrm{KB}, \mathrm{KC}$ and the coordinating framework oxygen atoms (Table $\mathrm{S} 3$ and Ref. [56]) decrease as a consequence of the shape modifications of both $8 \mathrm{MR}$ channel aperture and D6R. The distances between the cation in the main channel (KD) and $\mathrm{O} 4$ and $\mathrm{O} 6$ decrease as well. All these effects are more marked in the ZL/1FL system.

(ii) OFL-KD distance decreases in ZL/0.5FL and remains almost constant in ZL/1.0FL.

(iii) Compression induces the splitting of OFL/WI and C3/WJ sites, which in the $P_{\mathrm{amb}}$ structures of ZL/0.5FL and ZL/1FL samples [56], occupy single sites. After the splitting, WJ increases its distance from the framework $\mathrm{O} 2$ atom, approaching WI site (Table S3). After pressure release, the original positions are recovered in the ZL/0.5FL composite, while this does not happen in the ZL/1FL sample.

(iv) At $2 \mathrm{GPa}$, the shape, orientation and arrangement of the fluorenone molecules in the main channel do not change with respect to ambient pressure.

All these $P$-induced deformations are reversible and, once the pressure is released, the original features of the zeolite and the distances among the FL molecules are almost recovered (Tables 2, S2 and S3).

\subsection{Structure of the ZL/1.5FL Composite from First-Principles Molecular Dynamics}

As evidenced by the above-discussed data, XRPD refinements provided a satisfactory description of the P-induced structural modifications of the composites characterized by low and moderate dye content. On the other hand, the great number of low-occupancy sites found for water and fluorenone molecules and the high symmetry hindered the structural refinement of the sample containing the maximum amount of dye. Such a difficulty was previously encountered in the room pressure refinement of the $\mathrm{ZL} / 1.5 \mathrm{FL}$ composite and it was overcome by integrating the experimental data on cell parameters with theoretical modelling for the atomic coordinates [56].

Hence, encouraged by this result, we exploited again theoretical modelling for achieving an atomistic structural description of the ZL/1.5FL composite at high-pressure conditions. Practically, we used the room-pressure coordinates as an initial guess to determine the composite structure at cell parameters corresponding to $1.95 \mathrm{GPa}$ and we run first-principles molecular dynamics simulations for both $\mathrm{P}=P_{\mathrm{amb}}$ and $\mathrm{P}=1.95 \mathrm{GPa}$ in order to study the pressure-induced changes of the supramolecular organization inside the zeolite nanochannels at molecular-level detail.

The first remarkable observation is that the unique dye-architecture found at room pressure remains stable at high pressure conditions (Figure 7), with minimal alterations of its intermolecular distances and essentially without significant perturbation of the FL molecular geometry, apart from slight instantaneous distortions from the ideal gas-phase structure, mainly ascribable to thermal motion.

Significantly, the leading interaction stabilizing the confined fluorenone superstructure, i.e., the coordination to potassium cations, not only is maintained but it appears also to be, on average, strengthened upon compression. Indeed, by comparing the pair distribution functions relative to the K-OFL interaction, we deduce a significant shortening of the minimum coordination distance, which passes from 3.1 to $2.9 \AA$ in going from room pressure to $1.95 \mathrm{GPa}$ (Figure 8). Moreover, the splitting of the first maximum into two peaks becomes much more evident upon compression, indicating that the interaction of the carbonyl group and potassium may have different degrees of strength among the hyperconfined fluorenone molecules. Taken as a whole, these data indicate that the supramolecular architecture of dyes responds to pressure essentially by approaching with the carbonyl groups the potassium cations in the $12 \mathrm{MR}$ channel, without undergoing appreciable modifications of both intraand inter-molecular distances. 


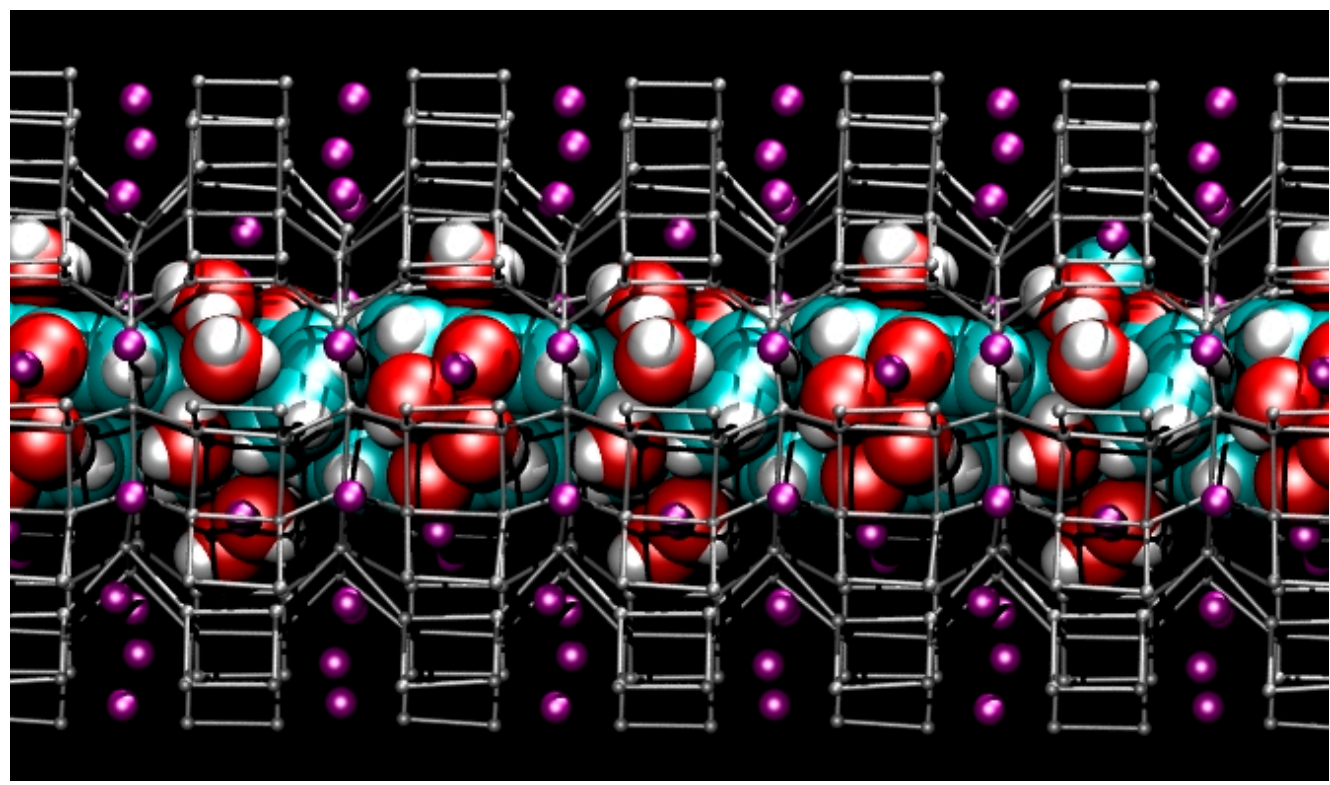

Figure 7. Snapshot from first-principles molecular dynamics (FPMD) simulation showing the structure of the hydrated ZL/1.5FL model with cell parameters corresponding to $\mathrm{P}=1.95 \mathrm{GPa}$ (side view of the $12 \mathrm{MR}$ channel || [001] axis). Colours are the same as reported in Figure 3.

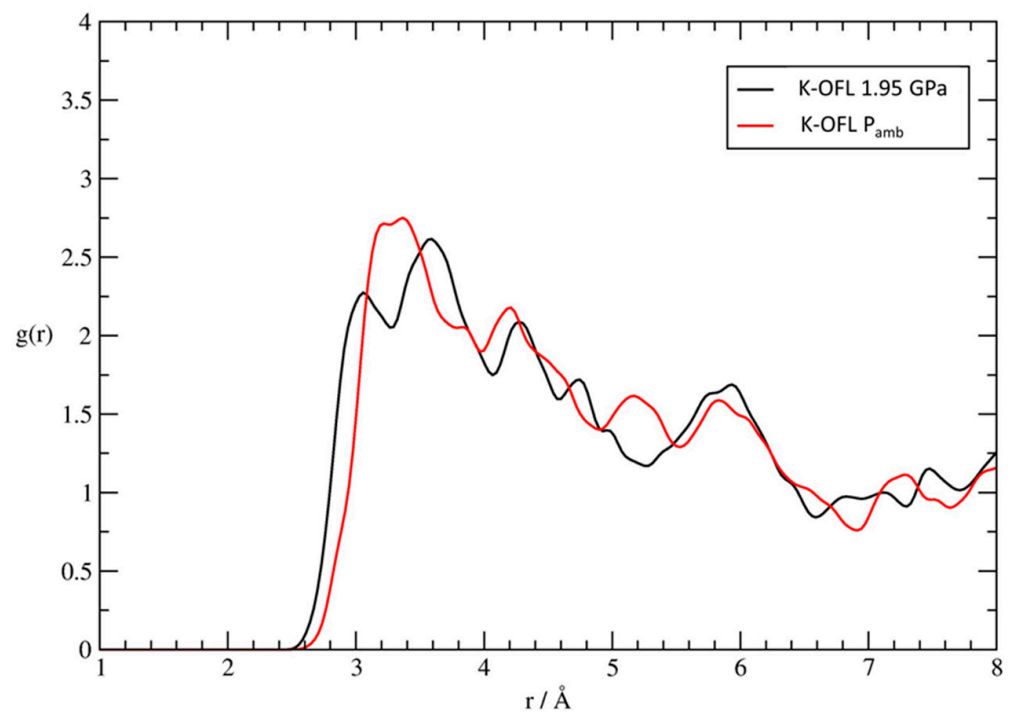

Figure 8. Pair distribution functions $g(r)$ from the room-temperature FPMD simulations relative to $P_{\mathrm{amb}}$ (red) and $\mathrm{P}=1.95 \mathrm{GPa}$ (black), calculated for the potassium extra framework cations of zeolite $\mathrm{L}$ with the carbonyl oxygens of fluorenone.

By considering now water molecules, which share the channel space with fluorenone, a striking similarity emerges by comparing their pair distribution functions at room pressure and $1.95 \mathrm{GPa}$ (Figure 9). Actually, for both water protons (Figure 9a) and water oxygens (Figure 9b) the two curves are almost superposable, showing also very close positions for first maximum peaks of water-water hydrogen bonding (corresponding, at room pressure, to $\mathrm{H}_{\mathrm{w}}-\mathrm{O}_{\mathrm{w}}$ and $\mathrm{O}_{\mathrm{w}}-\mathrm{O}_{\mathrm{w}}$ distances of 1.85 and $2.80 \AA$, respectively - see upper panels of Figure $9 a, b)$. In particular, only the shoulder of the $\mathrm{H}_{\mathrm{w}}-\mathrm{O}_{\mathrm{w}}$ peak-found at $1.78 \AA$ at $P_{\mathrm{amb}}$-appears to be very slightly displaced towards greater distances. Also the interaction of water with framework oxygens-which, as normally found for zeolitic water, 
is weaker than water-water hydrogen bonding [143-168] - appears to be nearly unperturbed upon compression and characterized by $\mathrm{H}_{\mathrm{w}}-\mathrm{O}_{\mathrm{f}}$ and $\mathrm{O}_{\mathrm{w}}-\mathrm{O}_{\mathrm{f}}$ distances of 1.95 and $2.90 \AA$, respectively (see centre panels of Figure $9 a, b$ ). Furthermore, the interaction of water with potassium cations is nearly unaffected by pressure at short range distances (with first maximum position at $2.90 \AA$, see Figure $9 \mathrm{~b}$, bottom panel), indicating that the coordination environment of the zeolite L extra framework cations is, on average, spectacularly insensitive to compression: no variation of the K coordination number occurs and distances from water oxygens remain basically unaltered. Finally, very minor changes are detected for the water-carbonyl interaction: the first peak position passes from 1.80 to $1.75 \AA$ upon compression, indicating a slightly stronger interaction of water molecules with the carbonyl group of the dye (Figure 9a, bottom panel).

Interestingly, whereas in the ZL/0.5FL and ZL/1FL composites the O6-O6 distance (i.e., the maximum diameter of the $12 \mathrm{MR}$ channel) either remains constant (ZL/1FL) or slightly shortens (ZL/0.5FL) with pressure (Table 2), such a distance increases in the ZL/1.5FL composite. Accordingly, the calculations also predict a decrease of the $12 \mathrm{MR}$ window (i.e., the channel opening) of ZL/1.5FL with compression (see O1-O1 and O2-O2 distances in Table 3). This behaviour is due to the peculiar close-packing arrangement of the extra framework content at maximum dye loading (ZL/1.5FL). Specifically, as compression occurs mainly along the channel axis, the guest species-water molecules and dye nanoladder - can only respond by further clustering in the maximum-diameter region of the channel (Figure 7), thus explaining the O6-O6 lengthening and the $12 \mathrm{MR}$ window narrowing. The different pressure response of the composites according to the dye loading is a consequence of the stiffening/template effects of the extra framework content, already observed in several high-pressure studies on zeolites and zeolite-based materials (see, e.g., Refs. $[62,63,66,77,81,139,169-171]$ ).

Taken together, besides the impressive stability of the fluorenone nanoladder, these results underline a quite surprising and important feature of the confined supramolecular system: even though water is smaller than the dye and hence in principle more easily displaceable upon compression, the arrangement of the water molecules in ZL/0.5FL and ZL/1FL is only slightly modified by the application of hydrostatic pressure-in particular, $\mathrm{WJ}$ increases its distance from the framework $\mathrm{O} 2$ atoms - and remains essentially unperturbed in ZL/1.5FL. This is ascribable to the fact that the $P_{\mathrm{amb}}$ structure of the ZL/1.5FL composite has already a close-packing arrangement of the extra framework species. In particular, all water molecules are fully stabilized by coordination to potassium cations and by the network of hydrogen-bond interactions with fluorenone carbonyl groups, water and framework oxygens [56].
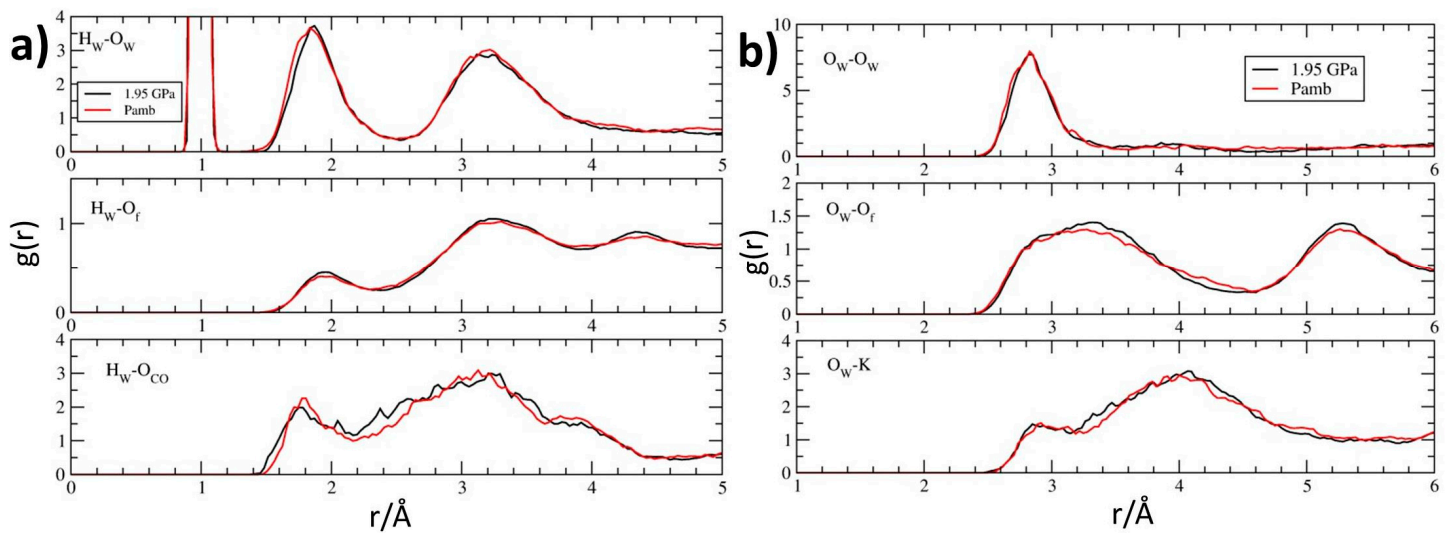

Figure 9. Pair distribution functions $\mathrm{g}(\mathrm{r})$ from the room-temperature FPMD simulations relative to $P_{\mathrm{amb}}$ (red) and $\mathrm{P}=1.95 \mathrm{GPa}$ (black), calculated for: (a) the water hydrogens $\mathrm{H}_{\mathrm{W}}$ with water oxygens $\mathrm{O}_{\mathrm{w}}$ (top), framework oxygens $\mathrm{O}_{\mathrm{f}}$ (middle), carbonyl oxygens $\mathrm{O}_{\mathrm{FL}}$ (bottom); (b) the water oxygens $\mathrm{O}_{\mathrm{w}}$ with water oxygens (top), framework oxygens $\mathrm{O}_{\mathrm{f}}$ (middle) and potassium cations (bottom). 
Table 3. Calculated average diameters of $12 \mathrm{MR}$ channel in $\AA$ from room-temperature FPMD simulations at different compression for the hydrated ZL/1.5FL system.

\begin{tabular}{ccc}
\hline Distance & $\boldsymbol{P}_{\mathbf{a m b}}$ & $\mathbf{1 . 9 5} \mathbf{G P a}$ \\
\hline O1-O1 & 9.934 & 9.878 \\
O2-O2 & 10.431 & 10.409 \\
O6-O6 & 15.520 & 15.614 \\
\hline
\end{tabular}

\section{Discussion}

The main motivation of our study was to elucidate the behaviour of luminescent hybrid materials, obtained via the inclusion of the fluorenone dye in zeolite L microcrystals, under compression. To answer this question, a thorough study has been performed using non-penetrating pressure transmitting fluid (silicon oil) in the high pressure X-ray diffraction experiments and complementing those results by ab initio molecular dynamics simulations, which allow to explore the finite temperature behaviour of the system at atomistic level detail.

If we consider that the technological applications of these composites rely on the presence of confined regular arrays of photoactive species, it is important to understand how this supramolecular organization of dye molecules responds to non-ambient conditions, specifically an applied pressure. Remarkably, all of the experiments and simulations evidenced the approaching of the fluorenone carbonyl group to potassium-i.e., the strengthening of the main stabilizing interaction in zeolite L composites with carbonyl dyes. Also notably, the applied pressure did not cause appreciable distortions of the molecular geometry of the chromophore, because of the zeolite framework ability to withstand compression effects, as already demonstrated in other high pressure studies of zeolites with non-penetrating fluids [135,138-140,169-171].

Experiments performed on the samples with low and medium fluorenone contents showed that the arrangement and the distances of the dye molecules, upon increasing pressure, do not change and their behaviour is consistent with the observed shortening of the $c$-parameter of the zeolite host. This pressure-induced shortening of intermolecular distances between dye molecules is however reversible upon returning to $P_{\mathrm{amb}}$, because it depends solely on non-covalent interactions. Also, such an effect is much less pronounced in the case of the high-concentrated composite (1.5FL/ZL), where the dye molecules are organized in a very close-packed arrangement already at room pressure conditions.

All these observations suggest that also the optical properties of the composites should not be significantly perturbed by external pressures of GPa-scale, an extremely important feature in the perspective of potential applications.

\section{Conclusions}

Overall, this study highlights the stability upon compression of the zeolite L/fluorenone adducts. This very important fact is of relevance in view of possible applications of such a kind of dye-zeolite composites at conditions different from the standard ones. We have also monitored an intriguing fluorenone-loading dependence of the system response to the applied pressure. However, some common features have been evidenced as well. In particular, compression brings about a strengthening of the fluorenone-zeolite L interactions, as shown by the shortening of the distance between the carbonyl oxygen atoms of the dye and the $\mathrm{K}^{+}$cations. Also, the molecular structure of the dye guests is barely influenced by compression. This is essentially due to the zeolite framework, which bears most of the compression effects-as evidenced by the (moderate) changes in the cell parameters and by the (moderate) changes in the $12 \mathrm{MR}$ channel-that are relevant for the zeolite pores volume. Such a framework stability upon compression induces only a modest variation of the pores volumes, which affects only to a minor extent the molecular structure of the organic guests. In conclusion, we have shown for the first time the stability towards pressure of dye-zeolite L adducts, which suggests 
that also the technologically relevant photophysical properties of these appealing materials could be exploited at high pressure conditions.

Supplementary Materials: The following are available online at www.mdpi.com/2073-4352/8/2/79/s1, Table S1: Unit-cell parameters of ZL/0.5FL, ZL/1FL, ZL/1.5FL samples at the investigated pressures; Table S2: Refined atomic positions, occupancy factors and displacement parameters of ZL/0.5FL and ZL/1FL at 2 GPa and upon decompression $\left(P_{\mathrm{amb}}(\mathrm{rev})\right)$; Table S3: Extra framework bond distances $<3.2 \AA$ for the ZL/0.5FL, ZL/1.0FL composites at $2 \mathrm{GPa}$ and upon decompression $\left(P_{\mathrm{amb}}(\mathrm{rev})\right)$.

Acknowledgments: BM01 beamline and the European Synchrotron Radiation Facility are acknowledged for the allocation of experimental beamtime. This work was supported by the Italian MIUR, within the frame of the following projects: PRIN2015 "ZAPPING" High-pressure nano-confinement in Zeolites: the Mineral Science know-how APPlied to engineerING of innovative materials for technological and environmental applications (2015HK93L7), ImPACT (FIRB RBFR12CLQD), and University of Insubria Far 2016.

Author Contributions: Rossella Arletti, Simona Quartieri, Giovanna Vezzalini, Gloria Tabacchi and Ettore Fois conceived the topic and designed the experiments; Lara Gigli, Rossella Arletti, Simona Quartieri, Giovanna Vezzalini, performed the experiments and analysed the data; Vladimir Dmitriev provided fundamental assistance during the experiments; Gloria Tabacchi and Ettore Fois performed the molecular dynamics simulations; all the authors contributed to write the paper.

Conflicts of Interest: The authors declare no conflict of interest. The founding sponsors had no role in the design of the study; in the collection, analyses, or interpretation of data; in the writing of the manuscript and in the decision to publish the results.

\section{References}

1. Baerlocher, C.; McCusker, L.B.; Olson, D.H. Atlas of Zeolite Framework Types; Elsevier: Amsterdam, The Netherland, 2007; ISBN 9780444530646.

2. Baur, W.; Fischer, R.X. Microporous and Other Framework Materials with Zeolite-Type Structures; Springer: Berlin, Germany, 2017; ISBN 9783662542514.

3. Čejka, J.; Centi, G.; Perez-Pariente, J.; Roth, W.J. Zeolite-based materials for novel catalytic applications: Opportunities, perspectives and open problems. Catal. Today 2012, 179, 2-15. [CrossRef]

4. Corma, A. Heterogeneous catalysis: Understanding for designing designing for applications. Angew. Chem. Int. Ed. 2016, 55, 6112-6113. [CrossRef] [PubMed]

5. Seifert, R.; Kunzmann, A.; Calzaferri, G. The yellow color of silver-containing zeolite A. Angew. Chem. Int. Ed. 1998, 37, 1521-1524. [CrossRef]

6. Baldansuren, A.; Roduner, E. EPR experiments of Ag species supported on NaA. Chem. Phys. Lett. 2009, 473, 135-137. [CrossRef]

7. Coutiño-Gonzalez, E.; Baekelant, W.; Steele, J.A.; Kim, C.W.; Roeffaers, M.B.J.; Hofkens, J. Silver clusters in zeolites: From self-assembly to ground-breaking luminescent properties. Acc. Chem. Res. 2017, 50, 2353-2361. [CrossRef] [PubMed]

8. Dong, B.; Retoux, R.; de Waele, V.; Chiodo, S.G.; Mineva, T.; Cardin, J.; Mintova, S. Sodalite cages of EMT zeolite confined neutral molecular-like silver clusters. Microporous Mesoporous Mater. 2017, 244, 74-82. [CrossRef]

9. Kim, H.S.; Yoon, K.B. Preparation and characterization of CdS and PbS quantum dots in zeolite Y and their applications for nonlinear optical materials and solar cell. Coord. Chem. Rev. 2014, 263-264, 239-256. [CrossRef]

10. Wang, Y.; Li, H. Luminescent materials of zeolite functionalized with lanthanides. CrystEngComm 2014, 16, 9764-9778. [CrossRef]

11. Calzaferri, G.; Huber, S.; Maas, H.; Minkowski, C. Host-guest antenna materials. Angew. Chem. Int. Ed. 2003, 42, 3732-3758. [CrossRef] [PubMed]

12. Hashimoto, S. Zeolite photochemistry: Impact of zeolites on photochemistry and feedback from photochemistry to zeolite science. J. Photochem. Photobiol. C Photochem. Rev. 2003, 4, 19-49. [CrossRef]

13. Alarcos, N.; Cohen, B.; Ziółek, M.; Douhal, A. Photochemistry and photophysics in silica-based materials: Ultrafast and Single molecule spectroscopy observation. Chem. Rev. 2017, 117, 13639-13720. [CrossRef] [PubMed] 
14. Busby, M.; Devaux, A.; Blum, C.; Subramaniam, V.; Calzaferri, G.; De Cola, L. Interactions of perylene bisimide in the one-dimensional channels of zeolite L. J. Phys. Chem. C 2011, 115, 5974-5988. [CrossRef]

15. Calzaferri, G.; Méallet-Renault, R.; Brühwiler, D.; Pansu, R.; Dolamic, I.; Dienel, T.; Adler, P.; Li, H.; Kunzmann, A. Designing dye-nanochannel antenna hybrid materials for light harvesting, transport and trapping. ChemPhysChem 2011, 12, 580-594. [CrossRef] [PubMed]

16. Gartzia-Rivero, L.; Bañuelos, J.; López-Arbeloa, I. Photoactive nanomaterials inspired by nature: LTL zeolite doped with laser dyes as artificial light harvesting systems. Materials (Basel) 2017, 10, 495. [CrossRef] [PubMed]

17. Martínez-Martínez, V.; García, R.; Gómez-Hortigüela, L.; Sola Llano, R.; Pérez-Pariente, J.; López-Arbeloa, I. Highly luminescent and optically switchable hybrid material by one-pot encapsulation of dyes into MgAPO-11 unidirectional nanopores. ACS Photonics 2014, 1, 205-211. [CrossRef]

18. Sola-Llano, R.; Fujita, Y.; Gómez-Hortigüela, L.; Alfayate, A.; Ujii, H.; Fron, E.; Toyouchi, S.; Perez-Pariente, J.; Lopez-Arbeloa, I.; Martinez-Martinez, V. One-directional antenna systems: Energy transfer from monomers to J-Aggregates within 1D nanoporous aluminophosphates. ACS Photonics 2017, 5, 151-157. [CrossRef]

19. Ramamurthy, V.; Lakshminarasimhan, P.; Grey, C.P.; Johnston, L.J. Energy transfer, proton transfer and electron transfer reactions within zeolites. Chem. Commun. 1998, 2411-2424. [CrossRef]

20. Calzaferri, G. Nanochannels: Hosts for the supramolecular organization of molecules and complexes. Langmuir 2012, 28, 6216-6231. [CrossRef] [PubMed]

21. Shim, T.; Lee, M.H.; Kim, D.; Kim, H.S.; Yoon, K.B. Fluorescence Properties of Hemicyanine in the Nanoporous Materials with Varying Pore Sizes. J. Phys. Chem. B 2009, 113, 966-969. [CrossRef] [PubMed]

22. Kim, D.; Kim, H.S. Enhancement of fluorescence from one- and two-photon absorption of hemicyanine dyes by confinement in silicalite-1 nanochannels. Microporous Mesoporous Mater. 2017, 243, 69-75. [CrossRef]

23. Doungmanee, S.; Siritanon, T.; Insuwan, W.; Jungsuttiwong, S.; Rangsriwatananon, K. Multi step energy transfer between three Si_LTL and SiGe_LTL zeolite-loaded dyes. J. Porous Mater. 2017, 1-9. [CrossRef]

24. Hu, D.D.; Lin, J.; Zhang, Q.; Lu, J.N.; Wang, X.Y.; Wang, Y.W.; Bu, F.; Ding, L.F.; Wang, L.; Wu, T. Multi-Step Host-Guest Energy Transfer Between Inorganic Chalcogenide-Based Semiconductor Zeolite Material and Organic Dye Molecules. Chem. Mater. 2015, 27, 4099-4104. [CrossRef]

25. Noh, T.H.; Jang, J.; Hong, W.; Lee, H.; Jung, O.-S. Truncated trigonal prismatic tubular crystals consisting of a zeolite L-mimic metal-organic framework. Chem. Commun. 2014, 50, 7451-7454. [CrossRef] [PubMed]

26. Ruiz, A.Z.; Brühwiler, D.; Ban, T.; Calzaferri, G. Synthesis of zeolite L. Tuning size and morphology. Monatshefte fur Chemie 2005, 136, 77-89. [CrossRef]

27. Cho, H.S.; Hill, A.R.; Cho, M.; Miyasaka, K.; Jeong, K.; Anderson, M.W.; Kang, J.K.; Terasaki, O. Directing the distribution of potassium cations in zeolite-LTL through crown ether addition. Cryst. Growth Des. 2017, 17, 4516-4521. [CrossRef]

28. Maas, H.; Calzaferri, G. Trapping energy from and injecting energy into dye-zeolite nanoantennae. Angew. Chem. Int. Ed. 2002, 41, 2284-2288. [CrossRef]

29. Brühwiler, D.; Calzaferri, G. Selective functionalization of the external surface of zeolite L. C. R. Chim. 2005, 8, 391-398. [CrossRef]

30. Dieu, L.-Q.; Devaux, A.; López-Duarte, I.; Victoria Martínez-Díaz, M.; Brühwiler, D.; Calzaferri, G.; Torres, T. Novel phthalocyanine-based stopcock for zeolite L. Chem. Commun. 2008, 0, 1187-1189. [CrossRef] [PubMed]

31. Li, P.; Wang, Y.; Li, H.; Calzaferri, G. Luminescence enhancement after adding stoppers to europium(III) nanozeolite L. Angew. Chem. Int. Ed. 2014, 53, 2904-2909. [CrossRef] [PubMed]

32. Tabacchi, G.; Fois, E.; Calzaferri, G. Structure of Nanochannel Entrances in Stopcock-Functionalized Zeolite L Composites. Angew. Chem. Int. Ed. 2015, 54, 11112-11116. [CrossRef] [PubMed]

33. Albuquerque, R.Q.; Popović, Z.; De Cola, L.; Calzaferri, G. Luminescence quenching by $\mathrm{O}_{2}$ of a $\mathrm{Ru}^{2+}$ complex attached to zeolite L. ChemPhysChem 2006, 7, 1050-1053. [CrossRef] [PubMed]

34. Beierle, J.M.; Roswanda, R.; Erne, P.M.; Coleman, A.C.; Browne, W.R.; Feringa, B.L. An improved method for site-specific end modification of zeolite $\mathrm{L}$ for the formation of zeolite $\mathrm{L}$ and gold nanoparticle self-assembled structures. Part. Part. Syst. Charact. 2013, 30, 273-279. [CrossRef]

35. Ramachandra, S.; Popović, Z.D.; Schuermann, K.C.; Cucinotta, F.; Calzaferri, G.; De Cola, L. Förster resonance energy transfer in quantum dot-dye-loaded zeolite L nanoassemblies. Small 2011, 7, 1488-1494. [CrossRef] [PubMed] 
36. Popović, Z.; Otter, M.; Calzaferri, G.; De Cola, L. Self-Assembling living systems with functional nanomaterials. Angew. Chem. Int. Ed. 2007, 46, 6188-6191. [CrossRef] [PubMed]

37. Strassert, C.A.; Otter, M.; Albuquerque, R.Q.; Hone, A.; Vida, Y.; Maier, B.; De Cola, L. Photoactive hybrid nanomaterial for targeting, labeling killing antibiotic-resistant bacteria. Angew. Chem. Int. Ed. 2009, 48, 7928-7931. [CrossRef] [PubMed]

38. Wang, Y.; Li, H.; Feng, Y.; Zhang, H.; Calzaferri, G.; Ren, T. Orienting zeolite L microcrystals with a functional linker. Angew. Chem. Int. Ed. 2010, 49, 1434-1438. [CrossRef] [PubMed]

39. Devaux, A.; Calzaferri, G.; Belser, P.; Cao, P.; Brühwiler, D.; Kunzmann, A. Efficient and robust host-guest antenna composite for light harvesting. Chem. Mater. 2014, 26, 6878-6885. [CrossRef]

40. Brühwiler, D.; Calzaferri, G.; Torres, T.; Ramm, J.H.; Gartmann, N.; Dieu, L.-Q.; López-Duarte, I.; Martínez-Díaz, M.V. Nanochannels for supramolecular organization of luminescent guests. J. Mater. Chem. 2009, 19, 8040-8067. [CrossRef]

41. Woodtli, P.; Giger, S.; Müller, P.; Sägesser, L.; Zucchetto, N.; Reber, M.J.; Ecker, A.; Brühwiler, D. Indigo in the nanochannels of zeolite L: Towards a new type of colorant. Dyes Pigments 2017, 149, 456-461. [CrossRef]

42. El-Gindi, J.; Benson, K.; De Cola, L.; Galla, H.J.; Seda Kehr, N. Cell adhesion behavior on enantiomerically functionalized zeolite L monolayers. Angew. Chem. Int. Ed. 2012, 51, 3716-3720. [CrossRef] [PubMed]

43. Greco, A.; Maggini, L.; De Cola, L.; De Marco, R.; Gentilucci, L. Diagnostic implementation of fast and selective integrin-mediated adhesion of cancer cells on functionalized zeolite L monolayers. Bioconjug. Chem. 2015, 26, 1873-1878. [CrossRef] [PubMed]

44. Fois, E.; Tabacchi, G.; Calzaferri, G. Interactions, behavior stability of fluorenone inside zeolite nanochannels. J. Phys. Chem. C 2010, 114, 10572-10579. [CrossRef]

45. Zhou, X.; Wesolowski, T.A.; Tabacchi, G.; Fois, E.; Calzaferri, G.; Devaux, A. First-principles simulation of the absorption bands of fluorenone in zeolite L. Phys. Chem. Chem. Phys. 2013, 15, 159-167. [CrossRef] [PubMed]

46. Fois, E.; Tabacchi, G.; Calzaferri, G. Orientation and order of xanthene dyes in the one-dimensional channels of zeolite L: Bridging the gap between experimental data and molecular behavior. J. Phys. Chem. C 2012, 116, 16784-16799. [CrossRef]

47. Viani, L.; Minoia, A.; Cornil, J.; Beljonne, D.; Egelhaaf, H.J.; Gierschner, J. Resonant energy transport in dye-filled monolithic crystals of zeolite L: Modeling of inhomogeneity. J. Phys. Chem. C 2016, 120, 27192-27199. [CrossRef]

48. Van Speybroeck, V.; Hemelsoet, K.; Joos, L.; Waroquier, M.; Bell, R.G.; Catlow, C.R.A. Advances in theory and their application within the field of zeolite chemistry. Chem. Soc. Rev. 2015, 44, 7044-7111. [CrossRef] [PubMed]

49. Calzaferri, G. Entropy in multiple equilibria, theory and applications. Phys. Chem. Chem. Phys. 2017, 19, 10611-10621. [CrossRef] [PubMed]

50. Tabacchi, G. Supramolecular Organization in Confined Nanospaces. ChemPhysChem 2018, in revision.

51. Manzano, H.; Gartzia-Rivero, L.; Bañuelos, J.; López-Arbeloa, I. Ultraviolet-visible dual absorption by single BODIPY dye confined in LTL zeolite nanochannels. J. Phys. Chem. C 2013, 117, 13331-13336. [CrossRef]

52. Cucinotta, F.; Guenet, A.; Bizzarri, C.; Mroz, W.; Botta, C.; Milian-Medina, B.; Gierschner, J.; De Cola, L. Energy transfer at the zeolite 1 boundaries: Towards photo- and electroresponsive materials. Chempluschem 2014, 79, 45-57. [CrossRef]

53. Fois, E.; Gamba, A.; Medici, C.; Tabacchi, G. Intermolecular electronic excitation transfer in a confined space: A first-principles study. ChemPhysChem 2005, 6, 1917-1922. [CrossRef] [PubMed]

54. Insuwan, W.; Rangsriwatananon, K.; Meeprasert, J.; Namuangruk, S.; Surakhot, Y.; Kungwan, N.; Jungsuttiwong, S. Combined experimental and theoretical investigation on photophysical properties of trans-azobenzene confined in LTL zeolite: Effect of cis-isomer forming. Microporous Mesoporous Mater. 2014, 197, 348-357. [CrossRef]

55. Insuwan, W.; Rangsriwatananon, K.; Meeprasert, J.; Namuangruk, S.; Surakhot, Y.; Kungwan, N.; Jungsuttiwong, S. Combined experimental and theoretical investigation on Fluorescence Resonance Energy Transfer of dye loaded on LTL zeolite. Microporous Mesoporous Mater. 2017, 241, 372-382. [CrossRef]

56. Gigli, L.; Arletti, R.; Tabacchi, G.; Fois, E.; Vitillo, J.G.; Martra, G.; Agostini, G.; Quartieri, S.; Vezzalini, G. Close-Packed dye molecules in zeolite channels self-assemble into supramolecular nanoladders. J. Phys. Chem. C 2014, 118, 15732-15743. [CrossRef] 
57. Gigli, L.; Arletti, R.; Tabacchi, G.; Fabbiani, M.; Vitillo, J.G.; Martra, G.; Devaux, A.; Miletto, I.; Quartieri, S.; Calzaferri, G.; et al. Structure and host-guest interactions of perylene-diimide dyes in zeolite 1 nanochannels. J. Phys. Chem. C 2018, accepted. [CrossRef]

58. Fois, E.; Tabacchi, G.; Devaux, A.; Belser, P.; Brühwiler, D.; Calzaferri, G. Host-guest interactions and orientation of dyes in the one-dimensional channels of zeolite L. Langmuir 2013, 29, 9188-9198. [CrossRef] [PubMed]

59. Tabacchi, G.; Calzaferri, G.; Fois, E. One-dimensional self-assembly of perylene-diimide dyes by unidirectional transit of zeolite channel openings. Chem. Commun. 2016, 52, 11195-11198. [CrossRef] [PubMed]

60. Arletti, R.; Ferro, O.; Quartieri, S.; Sani, A.; Tabacchi, G.; Vezzalini, G. Structural deformation mechanisms of zeolites under pressure. Am. Mineral. 2003, 88, 1416-1422. [CrossRef]

61. Gatta, G.D. A comparative study of fibrous zeolites under pressure. Eur. J. Mineral. 2005, 17, 411-422. [CrossRef]

62. Gatta, G.D. Does porous mean soft? On the elastic behaviour and structural evolution of zeolites under pressure. Zeitschrift für Kristallographie Cryst. Mater. 2008, 223, 160-170. [CrossRef]

63. Gatta, G.D.; Lee, Y. Zeolites at high pressure: A review. Mineral. Mag. 2014, 78, 267-291. [CrossRef]

64. Vezzalini, G.; Arletti, R.; Quartieri, S. High-pressure-induced structural changes, amorphization and molecule penetration in MFI microporous materials: A review. Acta Crystallogr. Sect. B Struct. Sci. Cryst. Eng. Mater. 2014, 70, 444-451. [CrossRef] [PubMed]

65. Fraux, G.; Coudert, F.-X.; Boutin, A.; Fuchs, A.H. Forced intrusion of water and aqueous solutions in microporous materials: From fundamental thermodynamics to energy storage devices. Chem. Soc. Rev. 2017, 46, 7421-7437. [CrossRef] [PubMed]

66. Gatta, G.D.; Lotti, P.; Tabacchi, G. The effect of pressure on open-framework silicates: Elastic behaviour and crystal-fluid interaction. Phys. Chem. Miner. 2017, 1-24. [CrossRef]

67. Lee, Y.; Vogt, T.; Hriljac, J.A.; Parise, J.B.; Hanson, J.C.; Kim, S.J. Non-framework cation migration and irreversible pressure-induced hydration in a zeolite. Nature 2002, 420, 485-489. [CrossRef] [PubMed]

68. Lee, Y.; Hriljac, J.A.; Parise, J.B.; Vogt, T. Pressure-induced hydration in zeolite tetranatrolite. Am. Mineral. 2006, 91, 247-251. [CrossRef]

69. White, C.L.I.M.; Ruiz-Salvador, A.R.; Lewis, D.W. Pressure-Induced Hydration Effects in the Zeolite Laumontite. Angew. Chem. Int. Ed. 2004, 43, 469-472. [CrossRef] [PubMed]

70. Lee, Y.; Kao, C.C.; Kim, S.J.; Lee, H.H.; Lee, D.R.; Shin, T.J.; Choi, J.Y. Water nanostructures confined inside the quasi-one-dimensional channels of LTL zeolite. Chem. Mater. 2007, 19, 6252-6257. [CrossRef]

71. Lee, Y.; Kim, S.J.; Ahn, D.C.; Shin, N.S. Confined water clusters in a synthetic rubidium gallosilicate with zeolite LTL topology. Chem. Mater. 2007, 19, 2277-2282. [CrossRef]

72. Seoung, D.; Lee, Y.; Kao, C.-C.; Vogt, T.; Lee, Y. Two-Step pressure-induced superhydration in small pore natrolite with divalent extra-framework cations. Chem. Mater. 2015, 27, 3874-3880. [CrossRef]

73. Cailliez, F.; Trzpit, M.; Soulard, M.; Demachy, I.; Boutin, A.; Patarin, J.; Fuchs, A.H. Thermodynamics of water intrusion in nanoporous hydrophobic solids. Phys. Chem. Chem. Phys. 2008, 10, 4817. [CrossRef] [PubMed]

74. Likhacheva, A.Y.; Seryotkin, Y.V.; Manakov, A.Y.; Goryainov, S.V.; Ancharov, A.I.; Sheromov, M.A. Pressure-induced over-hydration of thomsonite: A synchrotron powder diffraction study. Am. Mineral. 2007, 92, 1610-1615. [CrossRef]

75. Likhacheva, A.; Seryotkin, Y.; Manakov, A.; Goryainov, S.; Ancharov, A.; Sheromov, M. Anomalous compression of scolecite and thomsonite in aqueous medium to 2 GPa. High Press. Res. 2006, 26, 449-453. [CrossRef]

76. Arletti, R.; Vezzalini, G.; Quartieri, S.; Di Renzo, F.; Dmitriev, V. Pressure-induced water intrusion in FER-type zeolites and the influence of extraframework species on structural deformations. Microporous Mesoporous Mater. 2014, 191, 27-37. [CrossRef]

77. Arletti, R.; Vezzalini, G.; Morsli, A.; Di Renzo, F.; Dmitriev, V.; Quartieri, S. Elastic behavior of MFI-type zeolites: 1-Compressibility of Na-ZSM-5 in penetrating and non-penetrating media. Microporous Mesoporous Mater. 2011, 142, 696-707. [CrossRef]

78. Lotti, P.; Gatta, G.D.; Merlini, M.; Liermann, H.-P. High-pressure behavior of synthetic mordenite-Na: An in situ single-crystal synchrotron X-ray diffraction study. Zeitschrift für Kristallographie Cryst. Mater. 2015, 230, 201-211. [CrossRef] 
79. Comboni, D.; Gatta, G.D.; Lotti, P.; Merlini, M.; Hanfland, M. Crystal-fluid interactions in laumontite. Microporous Mesoporous Mater. 2018, 263, 86-95. [CrossRef]

80. Lotti, P.; Arletti, R.; Gatta, G.D.; Quartieri, S.; Vezzalini, G.; Merlini, M.; Dmitriev, V.; Hanfland, M. Compressibility and crystal-fluid interactions in all-silica ferrierite at high pressure. Microporous Mesoporous Mater. 2015, 218, 42-54. [CrossRef]

81. Lotti, P.; Gatta, G.D.; Comboni, D.; Merlini, M.; Pastero, L.; Hanfland, M. AlPO4-5 zeolite at high pressure: Crystal-fluid interaction and elastic behavior. Microporous Mesoporous Mater. 2016, 228, 158-167. [CrossRef]

82. Kim, Y.; Choi, J.; Vogt, T.; Lee, Y. Structuration under pressure: Spatial separation of inserted water during pressure-induced hydration in mesolite. Am. Mineral. 2018, 103, 175-178. [CrossRef]

83. Goryainov, S.V.; Secco, R.A.; Huang, Y.; Likhacheva, A.Y. Pressure-induced ionic conductivity of overhydrated zeolite NaA at different water/zeolite ratios. Microporous Mesoporous Mater. 2013, 171, 125-130. [CrossRef]

84. Lee, Y.; Lee, Y.; Seoung, D.; Im, J.H.; Hwang, H.J.; Kim, T.H.; Liu, D.; Liu, Z.; Lee, S.Y.; Kao, C.C.; et al. Immobilization of large, aliovalent cations in the small-pore zeolite K-natrolite by means of pressure. Angew. Chem. Int. Ed. 2012, 51, 4848-4851. [CrossRef] [PubMed]

85. Liu, D.; Chen, X.; Ma, Y.; Liu, Z.; Vogt, T.; Lee, Y. Spectroscopic and computational characterizations of alkaline-earth- and heavy-metal-exchanged natrolites. ChemPlusChem 2014, 79, 1096-1102. [CrossRef]

86. Im, J.; Seoung, D.; Hwang, G.C.; Jun, J.W.; Jhung, S.H.; Kao, C.-C.; Vogt, T.; Lee, Y. Pressure-Dependent structural and chemical changes in a metal-organic framework with one-dimensional pore structure. Chem. Mater. 2016, 28, 5336-5341. [CrossRef]

87. Kremleva, A.; Vogt, T.; Rösch, N. Monovalent cation-exchanged natrolites and their behavior under pressure. A computational study. J. Phys. Chem. C 2013, 117, 19020-19030. [CrossRef]

88. Kremleva, A.; Vogt, T.; Rösch, N. Potassium-exchanged natrolite under pressure. computational study vs experiment. J. Phys. Chem. C 2014, 118, 22030-22039. [CrossRef]

89. Santoro, M.; Gorelli, F.A.; Bini, R.; Haines, J.; van der Lee, A. High-pressure synthesis of a polyethylene/zeolite nano-composite material. Nat. Commun. 2013, 4, 1557. [CrossRef] [PubMed]

90. Santoro, M.; Dziubek, K.; Scelta, D.; Ceppatelli, M.; Gorelli, F.A.; Bini, R.; Thibaud, J.M.; Di Renzo, F.; Cambon, O.; Rouquette, J.; et al. High pressure synthesis of all-transoid polycarbonyl [-(C=O)-]n in a zeolite. Chem. Mater. 2015, 27, 6486-6489. [CrossRef]

91. Scelta, D.; Ceppatelli, M.; Santoro, M.; Bini, R.; Gorelli, F.A.; Perucchi, A.; Mezouar, M.; Van Der Lee, A.; Haines, J. High pressure polymerization in a confined space: Conjugated chain/zeolite nanocomposites. Chem. Mater. 2014, 26, 2249-2255. [CrossRef]

92. Santoro, M.; Scelta, D.; Dziubek, K.; Ceppatelli, M.; Gorelli, F.A.; Bini, R.; Garbarino, G.; Thibaud, J.M.; Di Renzo, F.; Cambon, O.; et al. Synthesis of 1D polymer/zeolite nanocomposites under high pressure. Chem. Mater. 2016, 28, 4065-4071. [CrossRef]

93. Jordá, J.L.; Rey, F.; Sastre, G.; Valencia, S.; Palomino, M.; Corma, A.; Segura, A.; Errandonea, D.; Lacomba, R.; Manjón, F.J.; et al. Synthesis of a novel zeolite through a pressure-induced reconstructive phase transition process. Angew. Chem. Int. Ed. 2013, 52, 10458-10462. [CrossRef] [PubMed]

94. Arletti, R.; Ronchi, L.; Quartieri, S.; Vezzalini, G.; Ryzhikov, A.; Nouali, H.; Daou, T.J.; Patarin, J. Intrusion-extrusion experiments of $\mathrm{MgCl} 2$ aqueous solution in pure silica ferrierite: Evidence of the nature of intruded liquid by in situ high pressure synchrotron X-ray powder diffraction. Microporous Mesoporous Mater. 2016, 235, 253-260. [CrossRef]

95. Arletti, R.; Leardini, L.; Vezzalini, G.; Quartieri, S.; Gigli, L.; Santoro, M.; Haines, J.; Rouquette, J.; Konczewicz, L. Pressure-induced penetration of guest molecules in high-silica zeolites: The case of mordenite. Phys. Chem. Chem. Phys. 2015, 17, 24262-24274. [CrossRef] [PubMed]

96. Santamaría-Pérez, D.; Marqueño, T.; MacLeod, S.; Ruiz-Fuertes, J.; Daisenberger, D.; Chuliá-Jordan, R.; Errandonea, D.; Jordá, J.L.; Rey, F.; McGuire, C.; et al. Structural evolution of $\mathrm{CO}_{2}$-filled pure silica LTA zeolite under high-pressure high-temperature conditions. Chem. Mater. 2017, 29, 4502-4510. [CrossRef]

97. Arletti, R.; Fois, E.; Gigli, L.; Vezzalini, G.; Quartieri, S.; Tabacchi, G. Irreversible Conversion of a water-ethanol solution into an organized two-dimensional network of alternating supramolecular units in a hydrophobic zeolite under pressure. Angew. Chem. Int. Ed. 2017, 56, 2105-2109. [CrossRef] [PubMed]

98. Car, R.; Parrinello, M. Unified approach for molecular dynamics and density-functional theory. Phys. Rev. Lett. 1985, 55, 2471-2474. [CrossRef] [PubMed] 
99. Gigli, L.; Arletti, R.; Quartieri, S.; Di Renzo, F.; Vezzalini, G. The high thermal stability of the synthetic zeolite K-L: Dehydration mechanism by in situ SR-XRPD experiments. Microporous Mesoporous Mater. 2013, 177, 8-16. [CrossRef]

100. Merrill, L.; Bassett, W.A. Miniature diamond anvil pressure cell for single crystal X-ray diffraction studies. Rev. Sci. Instrum. 1974, 45, 290-294. [CrossRef]

101. Miletich, R.; Allan, D.R.; Kuhs, W.F. High-Pressure single-crystal techniques. Rev. Mineral. Geochem. 2000, 41, 445-519. [CrossRef]

102. Angel, R.J.; Bujak, M.; Zhao, J.; Gatta, G.D.; Jacobsen, S.D. Effective hydrostatic limits of pressure media for high-pressure crystallographic studies. J. Appl. Crystallogr. 2007, 40, 26-32. [CrossRef]

103. Hammersley, A.P.; Svensson, S.O.; Hanfland, M.; Fitch, A.N.; Hausermann, D. Two-dimensional detector software: From real detector to idealised image or two-theta scan. High Press. Res. 1996, 14, $235-248$. [CrossRef]

104. Larson, A.C.; Von Dreele, R.B. General Structure Analysis System (GSAS) Program; Los Alamos National Laboratory: Los Alamos, NM, USA, 1994.

105. Toby, B.H. EXPGUI, a graphical user interface for GSAS. J. Appl. Crystallogr. 2001, 34, 210-213. [CrossRef]

106. Thompson, P.; Cox, D.E.; Hastings, J.B. Rietveld refinement of Debye-Scherrer synchrotron X-ray data from $\mathrm{Al}_{2} \mathrm{O}_{3}$. J. Appl. Crystallogr. 1987, 20, 79-83. [CrossRef]

107. Grimme, S. Semiempirical GGA-type density functional constructed with a long-range dispersion correction. J. Comput. Chem. 2006, 27, 1787-1799. [CrossRef] [PubMed]

108. Martínez-Suarez, L.; Siemer, N.; Frenzel, J.; Marx, D. Reaction network of methanol synthesis over Cu/ZnO Nanocatalysts. ACS Catal. 2015, 5, 4201-4218. [CrossRef]

109. Bandoli, G.; Barreca, D.; Gasparotto, A.; Seraglia, R.; Tondello, E.; Devi, A.; Fischer, R.A.; Winter, M.; Fois, E.; Gamba, A.; et al. An integrated experimental and theoretical investigation on $\mathrm{Cu}(\mathrm{hfa}) 2 \cdot \mathrm{TMEDA}$ : Structure, bonding and reactivity. Phys. Chem. Chem. Phys. 2009, 11, 5998-6007. [CrossRef] [PubMed]

110. Fois, E.; Tabacchi, G.; Barreca, D.; Gasparotto, A.; Tondello, E. "Hot" Surface activation of molecular complexes: Insight from modeling studies. Angew. Chem. Int. Ed. 2010, 49, 1944-1948. [CrossRef] [PubMed]

111. Martínez-Suárez, L.; Frenzel, J.; Marx, D. Cu/ZnO nanocatalysts in response to environmental conditions: Surface morphology, electronic structure, redox state and $\mathrm{CO}_{2}$ activation. Phys. Chem. Chem. Phys. 2014, 16, 26119-26136. [CrossRef] [PubMed]

112. Barreca, D.; Fois, E.; Gasparotto, A.; Seraglia, R.; Tondello, E.; Tabacchi, G. How does CuII convert into CuI? An unexpected ring-mediated single-electron reduction. Chem. Eur. J. 2011, 17, 10864-10870. [CrossRef] [PubMed]

113. Tabacchi, G.; Fois, E.; Barreca, D.; Gasparotto, A. Opening the Pandora's jar of molecule-to-material conversion in chemical vapor deposition: Insights from theory. Int. J. Quantum Chem. 2014, 114, 1-7. [CrossRef]

114. Pietrucci, F.; Andreoni, W. Fate of a graphene flake: A new route toward fullerenes disclosed with ab initio simulations. J. Chem. Theory Comput. 2014, 10, 913-917. [CrossRef] [PubMed]

115. Fois, E.; Gamba, A.; Tabacchi, G.; Coluccia, S.; Martra, G. Ab initio study of defect sites at the inner surfaces of mesoporous silicas. J. Phys. Chem. B 2003, 107, 10767-10772. [CrossRef]

116. Tabacchi, G.; Fois, E.; Barreca, D.; Gasparotto, A. CVD precursors for transition metal oxide nanostructures: Molecular properties, surface behavior and temperature effects. Phys. Status Solidi 2014, 211, 251-259. [CrossRef]

117. Kraus, P.; Frank, I. On the dynamics of $\mathrm{H}_{2}$ adsorption on the Pt(111) surface. Int. J. Quantum Chem. 2017, 117, e25407. [CrossRef]

118. Tabacchi, G.; Fois, E.; Barreca, D.; Carraro, G.; Gasparotto, A.; Maccato, C. Advanced Processing and Manufacturing Technologies for Nanostructured and Multifunctional Materials II; Ohji, T., Singh, M., Halbig, M., Eds.; Ceramic Engineering and Science Proceedings; John Wiley \& Sons, Inc.: Hoboken, NJ, USA, 2015; ISBN 9781119211662.

119. Maccato, C.; Bigiani, L.; Carraro, G.; Gasparotto, A.; Seraglia, R.; Kim, J.; Devi, A.; Tabacchi, G.; Fois, E.; Pace, G.; et al. Molecular engineering of Mn II diamine diketonate precursors for the vapor deposition of manganese oxide nanostructures. Chem. Eur. J. 2017, 23, 17954-17963. [CrossRef] [PubMed] 
120. Koizumi, K.; Nobusada, K.; Boero, M. Reducing the cost and preserving the reactivity in noble-metal-based catalysts: Oxidation of CO by Pt and Al-Pt alloy clusters supported on graphene. Chem. Eur. J. 2016, 22, 5181-5188. [CrossRef] [PubMed]

121. Deiana, C.; Tabacchi, G.; Maurino, V.; Coluccia, S.; Martra, G.; Fois, E. Surface features of $\mathrm{TiO}_{2}$ nanoparticles: Combination modes of adsorbed CO probe the stepping of (101) facets. Phys. Chem. Chem. Phys. 2013, 15, 13391-13399. [CrossRef] [PubMed]

122. Deiana, C.; Fois, E.; Martra, G.; Narbey, S.; Pellegrino, F.; Tabacchi, G. On the simple complexity of carbon monoxide on oxide surfaces: Facet-Specific donation and backdonation effects revealed on $\mathrm{TiO}_{2}$ anatase nanoparticles. ChemPhysChem 2016, 17, 1956-1960. [CrossRef] [PubMed]

123. Fois, E.; Gamba, A.; Tabacchi, G. Electronic spectra of Ti(IV) in zeolites: An ab initio approach. ChemPhysChem 2005, 6, 1237-1239. [CrossRef] [PubMed]

124. Fois, E.; Gamba, A.; Tabacchi, G. Structure and dynamics of a Brønsted acid site in a zeolite: An ab initio study of hydrogen sodalite. J. Phys. Chem. B 1998, 102, 3974-3979. [CrossRef]

125. Fois, E.; Gamba, A.; Tabacchi, G. First-principles simulation of the intracage oxidation of nitrite to nitrate sodalite. Chem. Phys. Lett. 2000, 329, 1-6. [CrossRef]

126. Tabacchi, G.; Silvi, S.; Venturi, M.; Credi, A.; Fois, E. Dethreading of a photoactive azobenzene-containing molecular axle from a crown ether ring: A computational investigation. ChemPhysChem 2016, 17, 1913-1919. [CrossRef] [PubMed]

127. Muñoz-Santiburcio, D.; Marx, D. Chemistry in nanoconfined water. Chem. Sci. 2017, 8, 3444-3452. [CrossRef] [PubMed]

128. Fois, E.; Gamba, A.; Tabacchi, G. Intracage chemistry: Nitrite to nitrate oxidation via molecular oxygen. A Car Parrinello study. Stud. Surf. Sci. Catal. 2001, 140, 251-268. [CrossRef]

129. Tabacchi, G.; Gianotti, E.; Fois, E.; Martra, G.; Marchese, L.; Coluccia, S.; Gamba, A. Understanding the vibrational and electronic features of Ti(IV) sites in mesoporous silicas by integrated ab initio and spectroscopic investigations. J. Phys. Chem. C 2007, 111, 4946-4955. [CrossRef]

130. Fois, E.; Gamba, A.; Spano, E.; Tabacchi, G. Rotation of molecules and ions in confined spaces: A first-principles simulation study. J. Mol. Struct. 2003, 644, 55-66. [CrossRef]

131. Spanó, E.; Tabacchi, G.; Gamba, A.; Fois, E. On the role of Ti(IV) as a Lewis acid in the chemistry of titanium zeolites: Formation, structure, reactivity aging of Ti-peroxo oxidizing intermediates. A first principles study. J. Phys. Chem. B 2006, 110, 21651-21661. [CrossRef] [PubMed]

132. Gamba, A.; Tabacchi, G.; Fois, E. TS-1 from first principles. J. Phys. Chem. A 2009, 113, $15006-15015$. [CrossRef] [PubMed]

133. Tabacchi, G.; Vanoni, M.A.; Gamba, A.; Fois, E. Does negative hyperconjugation assist enzymatic dehydrogenations? ChemPhysChem 2007, 8, 1283-1288. [CrossRef] [PubMed]

134. Trudu, F.; Tabacchi, G.; Gamba, A.; Fois, E. First principles studies on boron sites in zeolites. J. Phys. Chem. A 2007, 111, 11626-11637. [CrossRef] [PubMed]

135. Fois, E.; Gamba, A.; Medici, C.; Tabacchi, G.; Quartieri, S.; Mazzucato, E.; Arletti, R.; Vezzalini, G.; Dmitriev, V. High pressure deformation mechanism of Li-ABW: Synchrotron XRPD study and ab initio molecular dynamics simulations. Microporous Mesoporous Mater. 2008, 115, 267-280. [CrossRef]

136. Gatta, G.D.; Tabacchi, G.; Fois, E.; Lee, Y. Behaviour at high pressure of $\mathrm{Rb}_{7} \mathrm{NaGa}_{8} \mathrm{Si}_{12} \mathrm{O}_{40} \cdot 3 \mathrm{H}_{2} \mathrm{O}$ (a zeolite with EDI topology): A combined experimental-computational study. Phys. Chem. Miner. 2016, 43, $209-216$. [CrossRef]

137. Arletti, R.; Fois, E.; Tabacchi, G.; Quartieri, S.; Vezzalini, G. Pressure-Induced penetration of water-ethanol mixtures in all-silica ferrierite. Adv. Sci. Lett. 2017, 23, 5966-5969. [CrossRef]

138. Fois, E.; Gamba, A.; Tabacchi, G.; Quartieri, S.; Arletti, R.; Vezzalini, G. High-pressure behaviour of yugawaralite at different water content: An ab initio study. Stud. Surf. Sci. Catal. 2005, 155, 271-280. [CrossRef]

139. Ferro, O.; Quartieri, S.; Vezzalini, G.; Fois, E.; Gamba, A.; Tabacchi, G. High-pressure behavior of bikitaite: An integrated theoretical and experimental approach. Am. Mineral. 2002, 87, 1415-1425. [CrossRef]

140. Fois, E.; Gamba, A.; Tabacchi, G.; Ferro, O.; Quartieri, S.; Vezzalini, G. A theoretical investigation on pressure-induced changes in the vibrational spectrum of zeolite bikitaite. Stud. Surf. Sci. Catal. 2002, 142, 1877-1884. [CrossRef] 
141. Marx, D.; Hutter, J. Ab Initio Molecular Dynamics: Basic Theory and Advanced Methods; Cambridge University Press: Cambridge, UK, 2009; ISBN 9780511609633.

142. Copyright IBM Corp. 1990-2017; MPI für Festkörperforschung Stuttgart 1997-2001. CPMD Code: Car Parrinello Molecular Dynamics. Available online: http:/ / www.cpmd.org/.

143. Bougeard, D.; Smirnov, K.S. Modelling studies of water in crystalline nanoporous aluminosilicates. Phys. Chem. Chem. Phys. 2007, 9, 226-245. [CrossRef] [PubMed]

144. Demontis, P.; Gulín-González, J.; Masia, M.; Suffritti, G.B. The behaviour of water confined in zeolites: Molecular dynamics simulations versus experiment. J. Phys. Condens. Matter 2010, 22, 284106. [CrossRef] [PubMed]

145. Fois, E.; Gamba, A.; Tabacchi, G.; Quartieri, S.; Vezzalini, G. On the collective properties of water molecules in one-dimensional zeolitic channels. Phys. Chem. Chem. Phys. 2001, 3, 4158-4163. [CrossRef]

146. Quartieri, S.; Sani, A.; Vezzalini, G.; Galli, E.; Fois, E.; Gamba, A.; Tabacchi, G. One-dimensional ice in bikitaite: Single-crystal X-ray diffraction, infra-red spectroscopy and ab initio molecular dynamics studies. Microporous Mesoporous Mater. 1999, 30, 77-87. [CrossRef]

147. Fois, E.; Tabacchi, G.; Quartieri, S.; Vezzalini, G. Dipolar host/guest interactions and geometrical confinement at the basis of the stability of one-dimensional ice in zeolite bikitaite. J. Chem. Phys. 1999, 111, 355-359. [CrossRef]

148. Godelitsas, A.; Armbruster, T. HEU-type zeolites modified by transition elements and lead. Microporous Mesoporous Mater. 2003, 61, 3-24. [CrossRef]

149. Martucci, A.; Alberti, A.; de Lourdes Guzman-Castillo, M.; Di Renzo, F.; Fajula, F. Crystal structure of zeolite omega, the synthetic counterpart of the natural zeolite mazzite. Microporous Mesoporous Mater. 2003, 63, 33-42. [CrossRef]

150. Fois, E.; Gamba, A.; Tabacchi, G.; Quartieri, S.; Vezzalini, G. Water molecules in single file: First-principles studies of one-dimensional water chains in zeolites. J. Phys. Chem. B 2001, 105, 3012-3016. [CrossRef]

151. Ceriani, C.; Fois, E.; Gamba, A.; Tabacchi, G.; Ferro, O.; Quartieri, S.; Vezzalini, G. Dehydration dynamics of bikitaite: Part II. Ab initio molecular dynamics study. Am. Mineral. 2004, 89, 102-109. [CrossRef]

152. Demontis, P.; Gulín-Gonzalez, J.; Suffritti, G.B. Molecular dynamics simulation study of superhydrated perdeuterated natrolite using a new interaction potential model. J. Phys. Chem. B 2006, 110, 7513-7518. [CrossRef] [PubMed]

153. Demontis, P.; Gulìn-Gonzàlez, J.; Jobic, H.; Masia, M.; Sale, R.; Suffritti, G.B. Dynamical properties of confined water nanoclusters: Simulation study of hydrated zeolite NaA: Structural and vibrational properties. ACS Nano 2008, 2, 1603-1614. [CrossRef] [PubMed]

154. Trudu, F.; Tabacchi, G.; Gamba, A.; Fois, E. Water in acid boralites: Hydration effects on framework B sites. J. Phys. Chem. C 2008, 112, 15394-15401. [CrossRef]

155. Fois, E.; Gamba, A.; Trudu, F.; Tabacchi, G. $\mathrm{H}_{2} \mathrm{O}$-induced trigonal-to-tetrahedral transition in boron zeolites. Nuovo Cimento della Societa Italiana di Fisica. B Gen. Phys. Relativ. Astron. Math. Phys. Methods 2008, 123, 1567-1574. [CrossRef]

156. Wang, C.H.; Bai, P.; Siepmann, J.I.; Clark, A.E. Deconstructing hydrogen-bond networks in confined nanoporous materials: Implications for alcohol-water separation. J. Phys. Chem. C 2014, 118, 19723-19732. [CrossRef]

157. Zhou, T.; Bai, P.; Siepmann, J.I.; Clark, A.E. Deconstructing the confinement effect upon the organization and dynamics of water in hydrophobic nanoporous materials: Lessons Learned from zeolites. J. Phys. Chem. C 2017, 121, 22015-22024. [CrossRef]

158. Fois, E.; Gamba, A.; Tabacchi, G. Bathochromic effects in electronic excitation spectra of hydrated Ti zeolites: A theoretical characterization. ChemPhysChem 2008, 9, 538-543. [CrossRef] [PubMed]

159. Balestra, S.R.G.; Hamad, S.; Ruiz-Salvador, A.R.; Domínguez-García, V.; Merkling, P.J.; Dubbeldam, D.; Calero, S. Understanding nanopore window distortions in the reversible molecular valve zeolite RHO. Chem. Mater. 2015, 27, 5657-5667. [CrossRef]

160. Fischer, M. Water adsorption in SAPO-34: Elucidating the role of local heterogeneities and defects using dispersion-corrected DFT calculations. Phys. Chem. Chem. Phys. 2015, 17, 25260-25271. [CrossRef] [PubMed]

161. Fischer, M. Structure and bonding of water molecules in zeolite hosts: Benchmarking plane-wave DFT against crystal structure data. Zeitschrift für Kristallographie Cryst. Mater. 2015, 230, 325-336. [CrossRef] 
162. Fischer, M. Interaction of water with (silico)aluminophosphate zeotypes: A comparative investigation using dispersion-corrected DFT. Phys. Chem. Chem. Phys. 2016, 18, 15738-15750. [CrossRef] [PubMed]

163. Alabarse, F.G.; Haines, J.; Cambon, O.; Levelut, C.; Bourgogne, D.; Haidoux, A.; Granier, D.; Coasne, B. Freezing of water confined at the nanoscale. Phys. Rev. Lett. 2012, 109, 35701. [CrossRef] [PubMed]

164. Coudert, F.-X.; Vuilleumier, R.; Boutin, A. Dipole moment, hydrogen bonding and IR spectrum of confined water. ChemPhysChem 2006, 7, 2464-2467. [CrossRef] [PubMed]

165. Coudert, F.-X.; Cailliez, F.; Vuilleumier, R.; Fuchs, A.H.; Boutin, A. Water nanodroplets confined in zeolite pores. Faraday Discuss. 2009, 141, 377-398. [CrossRef] [PubMed]

166. Fischer, R.X.; Sehovic, M.; Baur, W.H.; Paulmann, C.; Gesing, T.M. Crystal structure and morphology of fully hydrated zeolite Na-A. Zeitschrift für Kristallographie 2012, 227, 438-445. [CrossRef]

167. Fois, E.; Gamba, A.; Tilocca, A. Structure and dynamics of the flexible triple helix of water inside VPI-5 molecular sieves. J. Phys. Chem. B 2002, 106, 4806-4812. [CrossRef]

168. Hernandez-Tamargo, C.E.; Roldan, A.; Ngoepe, P.E.; De Leeuw, N.H. Periodic modeling of zeolite Ti-LTA. J. Chem. Phys. 2017, 147, 74701. [CrossRef] [PubMed]

169. Fois, E.; Gamba, A.; Tabacchi, G.; Arletti, R.; Quartieri, S.; Vezzalini, G. The "template" effect of the extra-framework content on zeolite compression: The case of yugawaralite. Am. Mineral. 2005, 90, $28-35$. [CrossRef]

170. Betti, C.; Fois, E.; Mazzucato, E.; Medici, C.; Quartieri, S.; Tabacchi, G.; Vezzalini, G.; Dmitriev, V. Gismondine under HP: Deformation mechanism and re-organization of the extra-framework species. Microporous Mesoporous Mater. 2007, 103, 190-209. [CrossRef]

171. Ballone, P.; Quartieri, S.; Sani, A.; Vezzalini, G. High-pressure deformation mechanism in scolecite: A combined computational-experimental study. Am. Mineral. 2002, 87, 1194-1206. [CrossRef]

(C) 2018 by the authors. Licensee MDPI, Basel, Switzerland. This article is an open access article distributed under the terms and conditions of the Creative Commons Attribution (CC BY) license (http:/ / creativecommons.org/licenses/by/4.0/). 